IZADP No. 2201

Liquidity Constraints, Household Wealth, and Entrepreneurship Revisited

Robert W. Fairlie

HarryA. Krashinsky

July 2006 


\title{
Liquidity Constraints, Household Wealth, and Entrepreneurship Revisited
}

\author{
Robert W. Fairlie \\ University of California, Santa Cruz, \\ RAND and IZA \\ Harry A. Krashinsky \\ University of Toronto
Discussion Paper No. 2201
July 2006
(revision: October 2011)

IZA

P.O. Box 7240

53072 Bonn

Germany

Phone: +49-228-3894-0

Fax: +49-228-3894-180

Email: iza@iza.org

\begin{abstract}
Any opinions expressed here are those of the author(s) and not those of the institute. Research disseminated by IZA may include views on policy, but the institute itself takes no institutional policy positions.

The Institute for the Study of Labor (IZA) in Bonn is a local and virtual international research center and a place of communication between science, politics and business. IZA is an independent nonprofit company supported by Deutsche Post World Net. The center is associated with the University of Bonn and offers a stimulating research environment through its research networks, research support, and visitors and doctoral programs. IZA engages in (i) original and internationally competitive research in all fields of labor economics, (ii) development of policy concepts, and (iii) dissemination of research results and concepts to the interested public.
\end{abstract}

IZA Discussion Papers often represent preliminary work and are circulated to encourage discussion. Citation of such a paper should account for its provisional character. A revised version may be available directly from the author. 


\title{
ABSTRACT
}

\section{Liquidity Constraints, Household Wealth, and Entrepreneurship Revisited ${ }^{*}$}

\begin{abstract}
A large body research shows a positive relationship between wealth and entrepreneurship and interprets the relationship as providing evidence of liquidity constraints. Recently, however, the liquidity constraint interpretation has been challenged because of the finding that the relationship between business entry rates and assets is flat throughout most of the asset distribution and only rises dramatically after this point (Hurst and Lusardi 2004). We reexamine the liquidity constraint hypothesis in three ways. First, we demonstrate that examining the relationship separately for those who experience a job loss and those who do not reveals generally increasing entry rates through the wealth distribution for both groups. Based on the entrepreneurial choice model of Evans and Jovanovic (1989), these two groups face different incentives, and thus have different solutions to the entrepreneurial decision. We also find evidence of a stronger relationship between entrepreneurship and a different measure of wealth - net housing equity - for the two groups. Second, we examine the liquidity constraint hypothesis using a two-period simulation model that extends the Evans and Jovanovic (1989) model. The model shows how exogenous wealth shocks can be used to accurately identify the presence of liquidity constraints even allowing for endogenous saving and correlated abilities. Third, we provide new evidence from matched Current Population Survey (1993-2004) data to study whether changes in housing prices affect selfemployment entry. We find that housing appreciation measured at the MSA-level is a significantly positive determinant of entry into self-employment after controlling for changes in local economic conditions and other factors. Our estimates indicate that a 10 percent annual increase in housing equity increases the mean probability of entrepreneurship by 17 percent and that the effect is not concentrated at the upper tail of the distribution. These estimates are not sensitive to controlling for pre-existing trends in housing prices suggesting that the results are not being driven by expected local economic growth.
\end{abstract}

JEL Classification: J01

Keywords: entrepreneurship, liquidity constraints, housing wealth, self-employment

Corresponding author:

Robert W. Fairlie

University of California

Department of Economics

Engineering 2 Building

University of California

Santa Cruz, CA 95064

USA

E-mail: rfairlie@ucsc.edu

\footnotetext{
* We would like to thank Tom Astebro, Danny Blanchflower, Garth Frazer, Annamaria Lusardi, Rob McMillan, Simon Parker, Harvey Rosen, Herb Schuetze, David Scoones, Alexandra Spitz-Oener, Chris Woodruff, and participants at the NBER Entrepreneurship Workshop, Society of Labor Economists Meetings, and University of Victoria for helpful comments and suggestions. Oded Gurantz provided excellent research assistance.
} 


\section{$\underline{\text { Introduction }}$}

The relationship between wealth and business creation is one of the most important and well-studied questions in the rapidly expanding literature on entrepreneurship. Many studies document the positive relationship that exists between personal assets and the propensity to start a business, and interpret this result as providing evidence of the existence and importance of liquidity constraints. ${ }^{1}$ The interpretation of the finding is important because of its implications for justifying the provision of government loans and guarantees, the long-standing debate over the nature of entrepreneurship, and the potential economic inefficiencies created by liquidity constraints. $^{2}$ The current financial crisis has also brought the issue to the forefront because of the large and rapid decline in personal wealth and venture capital funding, and the severe tightening of credit to small businesses by banks. ${ }^{3}$

Recent evidence from the Panel Study of Income Dynamics (PSID), however, challenges the liquidity constraint interpretation. The positive relationship between asset levels and business entry rates is found to be driven almost entirely by extremely wealthy individuals (Hurst and Lusardi 2004). Entry rates are virtually constant for individuals between the $1^{\text {st }}$ and $95^{\text {th }}$ percentiles of the asset distribution, but increase drastically for individuals above the $95^{\text {th }}$ percentile. The constancy of entry rates for the majority of the asset distribution is inconsistent with the emphasis placed in the previous literature on the importance on liquidity constraints.

\footnotetext{
${ }^{1}$ See Evans and Jovanovic (1989), Evans and Leighton (1989), Meyer (1990), Holtz-Eakin, Joulfaian, and Rosen (1994), Lindh and Ohlsson (1996, 1998), Blanchflower and Oswald (1998), Dunn and HoltzEakin (1999), Fairlie (1999), Johansson (2000), Taylor (2001), Zissimopoulos and Karoly (2007, 2009), Holtz-Eakin and Rosen (2004), Giannetti and Simonov (2004), Nykvist (2005), and Bates and Lofstrom (2008).

${ }^{2}$ Knight (1921) argues that entrepreneurs generally self-finance and bear all of the risks because capital markets provide too little capital, whereas Schumpeter $(1934,1950)$ argues that modern capital markets generally allow the entrepreneur to find a capitalist to bear the risks (Evans and Jovanovic 1989).

${ }^{3}$ See PricewaterhouseCoopers and the National Venture Capital Association (2009) and Board of Governors of the Federal Reserve System (2009).
} 
Hurst and Lusardi (2004) conclude that even if some households are constrained from borrowing, "such constraints are not empirically important in deterring the majority of small business formation in the United States."

In this paper, we reexamine the liquidity constraint hypothesis in three ways. Motivated by the finding in Farber (1999) of high entry rates by displaced workers into "alternative" work arrangements such as self-employment, we examine the relationship between wealth and business creation separately for job losers and non-job losers. Although we find that the flat relationship between wealth and entrepreneurship throughout most of the wealth distribution is evident for the pooled sample of individuals, the result is not as well supported for the separate subsamples of job losers and non-job losers. Using the theoretical model of entrepreneurial choice by Evans and Jovanovic (1989), we demonstrate that the two groups face different incentives, and thus have different solutions to the entrepreneurial decision. This is due to the fact that some job losers would not have otherwise become self-employed had they not lost their jobs, opting for self-employment because of a negative shock to their career paths, wages and wealth. ${ }^{4}$ Alternatively, non-displaced entrants into self-employment are those who planned to ultimately own their own business, and become self-employed at a time that accords with this plan. Estimating separate equations by job displacement status implicitly controls for unobservable differences, and the possibility of reverse causation in which workers quit jobs to start businesses is ruled out by focusing only on involuntary job loss. When we examine the two subsamples separately, we find evidence of generally increasing rates of entry into selfemployment throughout the asset distribution.

\footnotetext{
${ }^{4}$ Farber (1999) has noted that alternative or contingent work arrangements are quite prevalent among displaced workers. One such "alternative" work arrangement is self-employment, which sees disproportionately high entry rates for many workers after job loss. In fact, Krashinsky (2005) shows that entry rates into self-employment for workers who lost their jobs are two or three times higher than entry rates for non-job losers.
} 
Further investigation reveals that the constant business entry rates through most of the asset distribution documented in Hurst and Lusardi (2004) are due to the changing proportion of job losers at each asset level. In particular, we find that job losers who have high entry rates are disproportionately located at the bottom of the wealth distribution and non-job losers who have low entry rates are disproportionately located near the top of the wealth distribution. Another interesting finding is that the positive relationship between entry rates and wealth in the two subsamples is stronger and more significant when we expand the sample size by focusing on net housing equity as the measure of wealth. These results are more consistent with the existence of liquidity constraints.

Addressing concerns about endogeneity in examining the relationship between wealth and entrepreneurship, previous studies have explored more exogenous measures of wealth such as inheritances and lottery winnings (e.g. Holtz-Eakin, Joulfaian and Rosen 1994; Lindh and Ohlsson 1996; Blanchflower and Oswald 1998). To examine the potential for this approach to identify causal effects, we simulate a two-period extension of the Evans and Jovanovic (1989) model that allows for correlation in ability and endogenous saving. Estimates from the simulations indicate that IV models accurately identify the presence of liquidity constraints even in the presence of this type of endogeneity and using sample sizes that roughly similar to those available in large, publicly-available data sets.

The third contribution to the literature is to use a relatively unexplored source of exogenous variation in wealth to test the liquidity constraint hypothesis - MSA-level and timeseries differences in unanticipated changes in housing equity. The approach improves on previous research that relies on broad regional differences in housing equity as an instrument for household wealth in the business entry equation in the PSID (Hurst and Lusardi 2004). We 
analyze the unanticipated housing instrument with data from matched Current Population Surveys (CPS) from 1993 to 2004, which include variation in unanticipated housing appreciation across a large number of metropolitan areas over a long period of time. The use of changes in net housing equity are also less subject to the LATE criticism for small samples of the population affected by the instrument (as discussed by Oreopoulos 2006) than the use of inheritance amounts or lottery winnings because of the relatively large fraction of the overall U.S. population that owns a home. Estimates from the CPS provide a different result than those from the PSID, which are based on less geographical variation and only one year. Housing appreciation is found to be a positive and statistically significant determinant of self-employment entry after controlling for changes in local economic conditions and the effect is not concentrated at the upper tail of the distribution. We also find that the estimates are not sensitive to controlling for pre-existing trends in housing prices suggesting that the results are not being driven by expected changes in local economic conditions.

\section{A Model of Entrepreneurship}

A theoretical analysis of the choice to become self-employed has generally been based upon a comparison of potential income from wage and salary work and self-employment. A model by Evans and Jovanovic (1989) relies upon a framework where an individual can obtain the following income, $\mathrm{Y}^{\mathrm{W}}$, from the wage and salary sector: $\mathrm{Y}^{\mathrm{W}}=\mathrm{w}+\mathrm{rA}$, where $\mathrm{w}$ is the wage earned in the market, $\mathrm{r}$ is the interest rate, and A represents the individual's assets. Earnings in the self-employment sector, $\mathrm{Y}^{\mathrm{SE}}$, are defined as: $\mathrm{Y}^{\mathrm{SE}}=\theta \mathrm{f}(\mathrm{k}) \varepsilon+\mathrm{r}(\mathrm{A}-\mathrm{k})$, where $\theta$ is entrepreneurial ability, $\mathrm{f}($.$) is a production function whose only input is capital, \varepsilon$ is a random component to the production process, and $\mathrm{k}$ is the amount of capital purchased by the worker. Three general 
solutions to the question of how the individual chooses to purchase capital exist. First, the individual purchases the profit maximizing level of capital, $\mathrm{k}^{*}$, which satisfies the first-order condition $\theta \mathrm{f}^{\prime}\left(\mathrm{k}^{*}\right)=\mathrm{r}$. Second, if $\mathrm{k}^{*}$ is unattainable due to liquidity constraints, instead of choosing $\mathrm{k}^{*}$ the worker chooses $\mathrm{k}^{\prime}$ such that $\mathrm{k}^{\prime}=\mathrm{L}(\mathrm{A})$, where $\mathrm{L}($.$) is a function that determines$ the maximum amount of liquidity the worker can obtain given his or her assets, A. In this case, $\mathrm{k}^{\prime}<\mathrm{k}^{*}$, resulting in a suboptimal level of $\mathrm{Y}^{\mathrm{SE}}$. Finally, if $\theta$ is sufficiently small the individual purchases no capital.

There are two key observations from this model that are relevant to this paper. The first is that because capital is purchased with assets, then the presence of liquidity constraints can discourage low-asset workers from entering self-employment. If liquidity-constrained individuals can only obtain sub-optimal earnings in self-employment, then many of these individuals will not enter self-employment (even though they might do so if their maximized earnings were available to them). Thus, the existence of increasing self-employment entry rates as assets rise is consistent with the existence of liquidity constraints.

To see this relationship, we follow Evans and Jovanovic (1989) by assuming that $\mathrm{f}(\mathrm{k})=$ $\mathrm{k}^{\alpha}$, resulting in self-employment income, $\mathrm{Y}^{\mathrm{SE}}=\theta \mathrm{k}^{\alpha} \varepsilon^{+} \mathrm{r}(\mathrm{A}-\mathrm{k})$. The individual chooses selfemployment if this income level is higher than income from the wage and salary sector. For individuals who are not liquidity constrained, the term rA cancels from both types of income, and the decision to become self-employment does not depend on wealth. Solving for the optimal level of capital, the unconstrained individual chooses self-employment if:

$$
\theta^{1 /(1-\alpha)}\left(\frac{\alpha}{r}\right)^{\alpha /(1-\alpha)}-r\left(\frac{\alpha}{r}\right)^{1 /(1-\alpha)} \theta^{1 /(1-\alpha)} \geq w
$$

The solution for the liquidity constrained individual is:

$$
\theta L(A)^{\alpha}-r L(A)>w
$$


In this equation, individuals with higher levels of assets are more likely to choose selfemployment holding everything else constant and assuming large enough values of $\theta$ and $\alpha$ compared with r. Combing these conditions, the general conditions for selection into selfemployment can be derived as in Evans and Jovanovic (1989). An individual chooses selfemployment if:

$$
\begin{aligned}
& w^{1-\alpha}\left(\frac{r}{\alpha}\right)^{\alpha}(1-\alpha)^{\alpha-1} \leq \theta \leq L(A)^{1-\alpha}\left(\frac{r}{\alpha}\right), \text { or } \\
& \theta>\max \left\{L(A)^{1-\alpha}\left(\frac{r}{\alpha}\right), w L(A)^{-\alpha}+r L(A)^{1-\alpha}\right\} .
\end{aligned}
$$

Evans and Jovanovic show that these general selection conditions imply a positive relationship between assets and self-employment.

The second observation to be made from this model is that although these selection conditions for entrepreneurship hold for individuals employed in the wage and salary sector, they need to be reinvestigated for individuals experiencing a job displacement. In particular, job losers are likely to face lower wages, w, than similar non-job losers if they seek re-employment in the wage and salary sector because of lost seniority, firm-specific human capital and other jobrelated characteristics that raise his or her wage. An extensive literature indicates sizeable wage and earnings losses associated with job displacement. ${ }^{5}$ Lower potential wages among job losers increase the likelihood of choosing self-employment all else equal. Also, because job losers are at least temporarily unemployed, displacement will alter their assets. Job losers may also react differently given the same wealth level because of their unwillingness to use their equity to finance business creation instead of for consumption and may face more difficulties in obtaining loans. Taken together, job loss alters the available wage and salary sector wage rate, w, and

\footnotetext{
${ }^{5}$ See Jacobsen, Lalonde and Sullivan (1993) and Farber (2004) for reviews of the literature.
} 
assets, A, which changes the conditions under which originally equivalent workers make the self-employment entry decision. It may also alter the relationship between these variables and the self-employment decision. Empirically, it is difficult to measure potential wages and selfemployment earnings. Job loss may also be correlated with other unobservables affecting the self-employment decision. Given these concerns, separate regressions for the self-employment entry decision will be estimated for job losers and non-job losers.

\section{Data}

We use data from the Panel Study of Income Dynamics (PSID) and matched Current Population Surveys (CPS) to explore the liquidity constraint hypothesis. The PSID provides a large, nationally representative panel dataset that allows for the identification of entrants into self-employment. The PSID is one of the few nationally representative, panel datasets that contains detailed wealth information for the individual. The use of the PSID also makes it easier to compare results to the recent findings of Hurst and Lusardi (2004) ${ }^{6}$ We also use panel data created by matching consecutive years of the Current Population Survey (CPS) Outgoing Rotation Group (ORG) files from 1994 to 2004. ${ }^{7}$ The CPS panel data allow us to exploit the variation in housing equity across a large number of metropolitan areas over a long period of time.

To reexamine the relationship between wealth and entrepreneurship through the wealth distribution based on Hurst and Lusardi’s (2004) findings, we use one similar wave and one

\footnotetext{
${ }^{6}$ The PSID has been used in previous research to answer a diverse set of questions about selfemployment and business ownership. See Holtz-Eakin, Penrod, and Rosen (1996), Fairlie (1999), Bruce (2000), Bradford (2003), Holtz-Eakin and Rosen (2005), and Parker (2008) for a few examples.

${ }^{7}$ Households in the CPS are interviewed each month over a 4-month period and 8 months later they are re-interviewed in each month of a second 4-month period. This rotation panel makes it possible to create a one-year panel for up to half of the respondents.
} 
different wave because of the availability of information on job loss. Hurst and Lusardi (2004) use the 1989 and 1994 waves of the PSID, whereas we use the 1984 and 1989 waves. The 1994 wave does not contain information on job loss. The only difference between the 1984 and 1989 waves is the way in which uncertainty over precise values of assets is approximated. ${ }^{8}$ In addition to collecting very detailed asset information in five year intervals (the 1984, 1989, 1994 and 1999 waves), the 1984, 1989 and 1999 waves of the PSID also contain information on job loss. Since we analyze the subsamples of respondents who enter self-employment after a job loss and not after a job loss, the 1984 and 1989 waves are well-suited for our work. Unfortunately, the 1999 wave of the survey is not ideal for our analysis of one-year transitions into self-employment, since the PSID did not survey its respondents in $2000 .{ }^{9}$ We conduct several additional analyses, however, that include more years of the PSID and different measures of assets.

Table 1 displays some summary statistics for our sample. As previously mentioned, we use the 1984 and 1989 waves of the PSID, and we consider two types of individuals not selfemployed in 1984 and 1989: those who become self-employed business owners in the following year, and those who do not become self-employed business owners. We follow the more common approach in the literature of analyzing entrants into self-employment instead of using household business ownership as in Hurst and Lusardi (2004). ${ }^{10}$ Household business ownership captures ownership of businesses by any household member and includes side or small-scale businesses owned by wage/salary workers. Self-employed business owners are defined by their

\footnotetext{
${ }^{8}$ In both the 1984 and 1989 wave, if the value of a particular asset (such as a house, other real estate, or the value of a savings account) is unknown to the respondent, the survey then asks "...would it be worth more than \$X?”, where X was an arbitrary amount. This amount changed during the two surveys (it was adjusted upwards for 1989), but this change does not have an impact on our results.

${ }^{9}$ The PSID began collecting its information in two-year intervals starting in 1997.

${ }^{10}$ See Fairlie and Robb (2008) for a review of empirical studies focusing on self-employment.
} 
main job activity and not by the activity of others in the household. We also focus on selfemployment for consistency with our analysis of the CPS, which is restricted to examining selfemployment entry. Nevertheless, we replicate our results using the PSID by analyzing entry into household business ownership and find similar results. ${ }^{11}$

We begin by pooling the entire sample in the first two columns of the Table, and the results attest to the general differences between the two groups. Clearly, the age and a general measure of education for the two sub-samples are quite similar, but they differ in their net worth. We also consider two different measures for net worth: the first is the household's total assets, defined as sum of savings and checking accounts, bonds, stocks, IRAs, housing equity (defined as the reported house value minus the remaining mortgage), other real estate, and vehicles minus all debt. ${ }^{12}$ The second measure considers only housing equity, which is defined as the difference between the self-reported house value and the remaining principal on the mortgage. Unlike the other asset measures, this variable is collected every year in the PSID, and is useful because it constitutes a large proportion of the respondent's net worth. ${ }^{13}$ Thus, it permits the analysis of the relationship between entry rates and a rough proxy for overall wealth in a larger sample. Both asset variables are measured prior to job loss to insure that they were not negatively impacted by the loss of jobs.

Both measures are significantly higher for the sample that enters self-employment, which is a standard finding that has been pointed to in previous research as providing evidence of liquidity constraints. In the next four columns, we make the same comparison for the two subsamples discussed earlier: columns three and four compare entrants and non-entrants who did not

\footnotetext{
${ }^{11}$ Hurst and Lusardi (2004) also note similar results for models of self-employment and household business entry.

${ }^{12}$ This is the same definition of net worth used by Hurst and Lusardi (2004).

${ }^{13}$ Specifically, $60 \%$ of the average homeowner's (and 64\% of the median homeowner's) assets are captured by net housing equity.
} 
experience job loss prior to entry, and columns five and six examine workers who experienced a job loss before entry. When comparing entrants to non-entrants, both subsamples demonstrate that entrants into self-employment have higher assets than non-entrants, and the job loss sample’s entrants tend to be slightly older and better-educated than non-entrants. But, there are other important issues to note when examining the two subsamples. A primary point is that each subsample contains a significant number of entrants into self-employment, so both groups represent large constituencies in this sector. Also, there are significant differences in the characteristics of the two groups: job-losers tend to be younger, less-educated and less wealthy in comparison with non-job-losers. Lastly, the entry rate for job losers is approximately $9 \%$, whereas only 3\% for the non-job loser sample enters self-employment. These differences suggest that a separate analysis of the relationship between assets and entry into self-employment is warranted for each group.

\section{Wealth and Entrepreneurship}

Numerous previous studies using various methodologies, measures of assets and international microdata explore the relationship between wealth and entrepreneurship. Most of these studies estimate the relationship by modeling the decision of non-business owners to switch into self-employment over a fixed period of time and generally find that wealth (e.g. net worth or asset income) measured in a given year are associated with a higher probability of entering self-employment by the following year. Previous research has examined the relationship between wealth and entrepreneurship using data from the United States (e.g. Evans and Jovanovic 1989; Evans and Leighton 1989; Meyer 1990; Holtz-Eakin, Joulfaian, and Rosen 1994; Fairlie 1999; Holtz-Eakin and Rosen 2004; Hurst and Lusardi 2004; Zissimopoulos and 
Karoly 2007, 2009; Bates and Lofstrom 2008; Demiralp and Francis 2008), Europe (e.g. Blanchflower and Oswald 1998; Lindh and Ohlsson 1996, 1998; Johansson 2000; Taylor 2001; Giannetti and Simonov 2004; Holtz-Eakin and Rosen 2004; Nykvist 2008; Schafer, Oleksandr and Weir 2010) and developing countries (e.g. Yu 2010; Paulson and Townsend 2004). ${ }^{14}$

Using the PSID, we reexamine the relationship between wealth and business entry. Figure 1 displays average entry rates for each asset category for the pooled sample, and both subsamples of workers. We do not display entry rates for individuals whose assets are in the $95^{\text {th }}$ percentile or higher because of much higher rates of entry, which would make it difficult to visually detect a relationship below these levels (see Appendix Figure 1). The plotted relationship for the pooled sample is similar to the finding in Hurst and Lusardi (2004) that entry into self-employment is almost identical across asset categories. Similar to Hurst and Lusardi (2004) we also find a large increase in entry rates for individuals whose assets are in the $95^{\text {th }}$ percentile or above. We see a jump of nearly 2.5 percentage points in entry rates when we compare this category to the $80^{\text {th }}$ to $95^{\text {th }}$ percentile group.

The constant pattern of entry rates disappears, however, when we consider the two subsamples independently as displayed in Figure 1. Both the non-job-loss sample and the job-loss sample exhibit increasing entry rates as wealth increases. We also find a much larger increase in entry rates at the $95^{\text {th }}$ percentile for the job-loss sample (0.22) than for the non-job loss sample (0.01). These results indicate that the jump in entry rates found for the pooled sample is being primarily driven by the job loser sample. This also speaks to the earlier issue of entry dynamics for those who do and do not lose their jobs prior to becoming self-employed. We find that selfemployment entrants who lost their jobs in the two wealthiest categories (80-95 $5^{\text {th }}$ and above $95^{\text {th }}$ percentile) have average hours of 48.75 and 45 hours per week suggesting that especially high rates of

${ }^{14}$ Also, see Parker (2009) and Kerr and Nanda (2010). 
entry are not a form of "disguised unemployment." Furthermore, we find that for all wealth/job loss groups average hours worked among self-employment entrants are high suggesting that a large share of reported self-employment is by unemployed workers. Appendix Table 2 also shows that after entering self-employment, job losers and non-job losers have significantly different industry concentrations. Finally, as presented below, we find that the impact of wealth on entry into self-employment is relatively greater for job-losers. These results together with the theoretical motivation provided by our model suggest that it is appropriate to treat the two groups separately given their significantly different behaviors.

The estimates displayed in Figure 1 also suggest that the unchanging entry rates for individuals at or below the $95^{\text {th }}$ percentile in the pooled sample are due to the changing frequencies of job losers as assets increase. About $60 \%$ of the job-loss sample has assets that are at or below the $40^{\text {th }}$ percentile in the distribution for the pooled sample, which is not surprising because the job-loss group was found to have lower assets overall (see Table 1). Job losers are less likely to fall into all of the higher wealth categories and the relative frequency of job-losers compared with non-job-losers decreases significantly moving up the wealth distribution. For example, only 6 percent of job losers are in the $80^{\text {th }}$ to $95^{\text {th }}$ percentile in the overall wealth distribution compared to 14 percent of non-job losers. This is important because it is this changing relative frequency between the two samples that causes the pooled sample to exhibit a constant entry rate over this asset range, even though each sub-sample exhibits increasing entry rates as assets rise. ${ }^{15}$ Higher entry rates for the job-loss sample than for the non-job-loss sample and generally increasing entry rates with wealth for both groups implies that a relative decrease in the frequency of job losers as assets rise causes the pooled entry rate to remain constant over the wealth distribution. Overall, this evidence has important implications for an interpretation of

\footnotetext{
${ }^{15}$ Additionally, the lack of finding of a strong positive relationship between wealth and business entry for the pooled sample may be partly due to measurement error.
} 
the entry rate dynamics in the pooled sample. Although it is clear that there are unchanging entry rates in the pooled sample for most of the asset distribution, this is not true for the two subsamples we analyze. Thus, unchanging entry rates in the pooled sample may be misleading evidence against the significance of liquidity constraints. ${ }^{16}$

As supporting evidence, Figure 2 also displays evidence on entry rates, but instead of using assets as the determinant of wealth, we use net house values. ${ }^{17}$ This is a reasonably good measure of wealth because net house values accounts for $60 \%$ of total assets, on average, for homeowners. The advantage of this measure is that this information is collected in almost all years of the PSID before 1993 (when job loss information is no longer collected) ${ }^{18}$ A disadvantage, however, is that there are wealthy non-home-owners in the sample. Using this measure of wealth, we now find a positive relationship even in the pooled sample. But, more importantly, we find stronger positive relationships between entry rates and net house values for both subsamples than when we used net worth as the measure of wealth. For non-job losers, the entry rate increases from 1.8 to 2.8 percent when net house values increase from the less than $20^{\text {th }}$ percentile group to the $80^{\text {th }}$ to $95^{\text {th }}$ percentile group. For job losers, the entry rate increases from 5.7 to 12.4 percent. The estimates also indicate the large jump in entry occurring at the $95^{\text {th }}$ percentile, but the jump is smaller. Overall, the estimates for net house values provide stronger evidence of a positive relationship between self-employment entry and wealth among non-job losers and job losers. ${ }^{19}$

\footnotetext{
${ }^{16}$ Cagetti and De Nardi (2006) also show that the relatively flat relationship between entrepreneurship and wealth throughout most of the wealth distribution can be generated from a model of entrepreneurial choice with borrowing constraints. See also Fonseca, Michaud, and Sopraseuth (2007).

${ }^{17}$ Entry rates for the full distribution are reported in Appendix Figure 1A.

${ }^{18}$ The previous results are somewhat sensitive to changes in the sample. For example, removing a few self-employment entrants or non-entrants from various cells can impact the pattern on entry rates over the wealth distribution. Larger sample sizes remove this problem.

${ }^{19}$ We compared the relationship between entry rates and total net worth to the relationship between entry
} 
To consider the findings in a regression context, Table 2 estimates logit entry regressions and uses different approaches to document the relationship between wealth and entry rates in the pooled, job loser and non-job loser samples. ${ }^{20}$ First, in columns one, four and seven, we regress an entry indicator variable on overall wealth for the pooled sample, and both sub-samples. In all three cases, there is a significant linear relationship between asset wealth and propensity to become self-employed, which is consistent with the previous literature. In columns two, five and eight, self-employment entry is regressed on a set of indicator variables that account for the asset percentile categories displayed in Figure 1. The findings for the non-job loser and job loser samples are consistent with the results reported in Figure $1 .{ }^{21}$ We generally find that the probability of self-employment entry increases throughout the asset distribution for the two subsamples, but relatively small sample sizes make our coefficient estimates somewhat imprecise. However, this imprecision is unavoidable with total net worth data from the PSID -given the relatively low entry rates into self-employment (about three percent in the overall sample). To deal with this sample size constraint, we also use net house values as the measure of assets in columns three, six and nine. As noted above, net housing equity is a good measure of wealth, comprising approximately $60 \%$ of an average homeowner's net worth, and it is collected in almost every year of the PSID. This new measure addresses the main weakness of the results using total assets -- the large standard errors on the coefficient estimates.

rates and net house values using the same survey years (1984 and 1989) and find similar entry patterns over the wealth distribution. These results are consistent with net housing equity representing a good proxy for net total net worth.

${ }^{20}$ Job loss may be correlated with unobservables affecting the self-employment decision. Estimating separate regressions removes any potential bias due to the correlation between job loss and unobservables. Separate regressions also allow the determinants of self-employment to differ between job losers and non-job losers. We find that the null hypothesis of similar job loser and non-job loser coefficients is easily rejected.

${ }^{21}$ We also find roughly similar patterns when we estimate specifications that also include 1994 data. The PSID does not include a measure of job loss in 1994 so we approximate it by examining employment information. 
Using net house values as the measure of assets, we find two important results. ${ }^{22}$ The first set of important findings is the increasing entry rates throughout the wealth distribution even for the pooled sample. More importantly, the larger sample sizes associated with this measure of wealth also results in the probability of becoming self-employed being significantly higher than the excluded category ( $1^{\text {st }}$ to $40^{\text {th }}$ percentile) for virtually every asset category displayed in the table. For both the job loser and non-job loser subsamples, entry rates gradually increase as net house values rise. These rates are significantly higher than the excluded group (net house value is below the $40^{\text {th }}$ percentile) for almost all categories, and this runs counter to the hypothesis that entry rates are unchanging from the first to the eightieth or ninety-fifth percentiles of the asset distribution. In fact, these results are consistent with the existence of liquidity constraints. The use of net house values also confirms the finding that the jump in entry rates at the $95^{\text {th }}$ percentile in wealth is much larger for job losers than non-job losers. The second important finding from Table 2 is that the estimation results which use asset and housing data generate very similar coefficient estimates on the indicator variables representing different quantiles in the asset distribution. This similarity suggests that both measures are effective at representing net worth, and that increased precision resulting from larger sample sizes allows for a more accurate analysis of the relationship between wealth and self-employment.

The analysis of the relationship between net house equity and entry rates is further explored in Table 3. We estimate three sets of entry regressions using different wealth groupings and sample years from the PSID as robustness checks. In columns one, four and seven, the 1979 to 1993 sample is used to consider entry rates for respondents in the $40^{\text {th }}$ to $80^{\text {th }}$ percentiles, $80^{\text {th }}$ to $95^{\text {th }}$ percentiles and above the $95^{\text {th }}$ percentiles. The $40^{\text {th }}$ to $60^{\text {th }}$ and $60^{\text {th }}$ to $80^{\text {th }}$ percentiles are

\footnotetext{
${ }^{22}$ We also find a significant linear relationship between net house equity and the propensity to become selfemployed for all three samples, and find a significantly larger positive relationship for the job loser sample than the non-job loser sample.
} 
collapsed the increase estimation precision. For all three samples, respondents in the $40^{\text {th }}$ to the $80^{\text {th }}$ percentile category exhibit statistically significantly higher entry rates than those in the 0 to $40^{\text {th }}$ percentile group. These findings differ from those presented in Hurst and Lusardi (2004) indicating no significant variation in entry rates below the $80^{\text {th }}$ percentile.

The remaining columns of Table 3 report estimates from expanded samples of the PSID to check the sensitivity of results. First, in columns two, five and eight, we expand our sample to include the years 1979 to 1996. From 1994 to 1996, the PSID did not collect information on job loss, but does contain information on spells of unemployment. Although this is not a perfect measure of involuntary job loss, it will capture some displaced workers. The sample used in columns three, six and nine further expands the sample by including the years 1997 to 2001, for which the PSID conducted interviews only every other year. We define entrants as those who become self-employed in the following interview. Results using these larger sample sizes, continue to display generally increasing entry rates throughout the housing equity distribution for all three samples consistent with the liquidity constraint hypothesis.

A significant finding in the results that we have not directly addressed is the sharp rise in entry rates above the $95^{\text {th }}$ percentile in the asset distribution. Two potential reasons may account for this entry spike: first, extremely wealthy households have a much higher tolerance for risk than lower asset households (Hurst and Lusardi 2004). Because self-employment is riskier than employment in the wage and salary sector, then high-asset households should be more likely to become self-employed. Self-employment may also be regarded as a kind of luxury good; therefore, as assets rise, there should be a corresponding (and disproportionately higher) increase in the propensity to become self-employed (Hurst and Lusardi 2004). 
An alternative explanation for this finding exits, however. Our evidence demonstrates that the job-loser sample exhibits a much larger increase in entry rates than the non-job loser sample at the $95^{\text {th }}$ percentile of wealth. We investigate this further by comparing the average age of each subsample by asset category in Table 4 to determine the characteristics of these wealthier job losers. The first column demonstrates that average age of all workers is increasing in our sample as assets increase, and the second column shows that this is also true for workers who entered self-employment in either 1985 or 1990. This is not surprising, because it takes time to accumulate assets, and the same pattern is evident for both job losers and non-job-losers. For both job losers and non-job losers, the average age is roughly 50 years old for the highest asset level, which is considerably higher than for lower asset categories.

This result provides insight into the rationale for the entry spike among wealthier job losers. Many authors have written about the negative consequences of job loss for older workers (see McCall 1997, Farber 2004, and Chan and Stevens 1999, 2001 for example). In particular, Chan and Stevens have analyzed the increased propensity of older workers who suffer job loss to become retired, since they face worsened employment prospects in many respects after involuntary job loss. Specifically, older workers who search for a job in the wage and salary sector require significant search time. Also, if they are re-employed in this sector, their earnings losses (in comparison to the pre-displacement job) are quite large, and they tend to have a decreased attachment to the labor market due to fewer hours worked per week, and a greater likelihood of working at a part-time job. As a result, the spike in entry rates may be attributable to the fact that with severely worsened wage-and-salary options, relatively older displaced workers may need to create employment for themselves, which can be accomplished in the selfemployment sector. 


\section{Self-Employment Entry and the Endogeneity of Wealth}

Although the largest source of startup capital by firms is personal and family savings and the majority of small business loans require personal commitments by owners (U.S. Census Bureau 2006 and Avery, Bostic and Samolyk 1998), there remains the concern that the finding of a positive relationship between wealth and entrepreneurship captures correlated unobservables instead of causal effects. ${ }^{23}$ In particular, the positive correlation between initial asset levels and self-employment entry may be the result of household's asset accumulation being related to its underlying entrepreneurial ability or saving in anticipation of starting a business. ${ }^{24}$

One manner in which it is possible to illustrate this endogeneity problem is with a monte carlo exercise. We do so by relying upon the Evans and Jovanovic (1989) model, and extend it to a two-period model in which individuals are assumed to be risk-averse, and utility is determined by consumption in both periods:

$$
U\left(C_{1}, C_{2}\right)=C_{1}^{1 / 2}+\frac{1}{1+r} C_{2}^{1 / 2}
$$

where $C_{\mathrm{t}}$ represents consumption in period $t$, where $t=1$,2. Individuals maximize utility subject to the following budget constraint:

$$
C_{1}+\frac{1}{1+r} C_{2}=Y_{1}+\frac{1}{1+r} Y_{2}
$$

where $Y_{\mathrm{t}}$ represents income in period $t$. Following Evans and Jovanovic (1989), income from the wage and salary sector in period one, $Y_{1}{ }^{W}$, is determined by a draw from a cumulative gamma

\footnotetext{
${ }^{23}$ Additionally, family resources are found to be positively correlated with startup capital controlling for other owner and business characteristics (Astebro and Bernhardt 2004).

${ }^{24}$ Previous research indicates that entrepreneurs have higher savings rates than non-entrepreneurs (Buerra 2006; Bradford 2003; Quadrini 1999; Gentry and Hubbard 2004).
} 
distribution. ${ }^{25}$ Period two income from the wage and salary sector, $Y_{2}{ }^{W}$ is determined by an AR(1) process. Specifically, $Y_{2}{ }^{W}=(1.1) Y_{1}{ }^{W}+u$, where u is a normally distributed error term. ${ }^{26}$ In period one, individuals are unaware of the value of $u$, and as such are acting to maximize their expected utility. Individuals are also assigned an amount of assets, $A$, which is determined by a random draw from a gamma distribution, and are available to the individual in period one. ${ }^{27}$ Income in the self-employment sector, $Y^{S E}$, is determined using a production function for unconstrained and constrained entrepreneurs, respectively:

$$
\begin{aligned}
& Y^{S E}=\theta k^{\alpha} \varepsilon+(A-k) \text { if } A>k, \text { and } \\
& Y^{S E}=\theta k^{\alpha} \varepsilon \text { if } A \leq k
\end{aligned}
$$

where $\theta$ represents entrepreneurial skill, k represents the amount of capital invested in the firm, and $\varepsilon$ is a randomly-distributed error component for the production function. ${ }^{28}$ Liquidity constraints result from the assigned combinations of $\theta$ and $A$ across individuals. Capital is purchased at a price normalized to one, and whatever assets are not used to purchase capital are available as income. As before, individuals do not know the period two value of $\varepsilon$ in period one, so they will act to maximize expected utility.

To address one source of potential endogeneity we allow $\theta$ to be correlated with wage and salary income, implying that more skilled workers in that sector are also more skilled in the self-employment sector. ${ }^{29}$ Another endogeneity concern is that individuals may save more or

\footnotetext{
${ }^{25}$ The gamma distribution has a shape parameter of 2, and is multiplied by a constant term in order to give it a mean of approximately $\$ 25,000$, which is reasonably close to actual values within the PSID data. ${ }^{26}$ The error term has a mean of 0 and variance of 500 , which is consistent with characteristics of our data.

${ }^{27}$ The gamma distribution has a shape parameter of 2 . The distribution function is multiplied by a constant term in order to give it a mean of approximately $\$ 40,000$, which is reasonably close to actual values in the PSID data.

${ }^{28} \varepsilon$ is normally distributed with a mean equal to 1 and a variance equal to 0.1 .

${ }^{29}$ The correlation between $\theta$ and wage and salary earnings is achieved by setting $\theta=(0.01) \mathrm{Y}^{\mathrm{WS}}+400+$ $\omega$, where $\omega$ is an error term with mean zero and variance of 400 . Simulations are also run without the correlation between $\theta$ and $\mathrm{Y}^{\mathrm{WS}}$, and the results are generally similar to those in Table 6 , with somewhat
} 
less depending on their draw of $\theta$. Thus, it is important to consider how exogenous changes in assets affect the propensity to become self-employed. As a result, exogenous shocks to assets are included in this model by randomly assigning an additional $\$ 20,000$ in assets to ten percent of the sample. ${ }^{30}$

To investigate whether the empirical approach that we take below can identify the presence of liquidity constraints, we estimate several regressions with simulated data. We focus on the self-employment entry decision, although individuals are free to choose to situate themselves in the wage and salary or self-employment sectors in both periods. Entry is captured by an indicator variable equal to one if the individual is in the wage and salary sector in the first period and the self-employment sector in the second period. The entry variable equals zero if the individual is in the wage and salary sector in both periods. Table 5 reports 2SLS estimates for regressions of self-employment entry on wealth using the simulated data with sample sizes ranging from 1,500 to 50,000 observations and $\alpha$ ranging from 0.15 to $0.4 .^{31}$ The instrumental variable for the 2SLS model is an indicator variable equal to one if the individual received the random asset shock. For all combinations of sample sizes and $\alpha$, the 2SLS estimates indicate a positive and statistically significant relationship between self-employment entry and the wealth shock. ${ }^{32}$ As expected, the relationship strengthens as the returns to capital increase, and the precision of estimates increases with the sample size.

Although the results of these simulations are only suggestive, they provide a couple of useful insights for the empirical strategy that follows. First, the simulations demonstrate that the

smaller standard errors.

${ }^{30}$ The $\$ 20,000$ inheritance was generally equivalent to the average value of inheritances received by individuals in our PSID sample in 1984 and 1989.

${ }^{31}$ Various articles in the literature on production functions suggest that $\alpha$ is within this range.

${ }^{32}$ OLS estimates from simulated data that do not include the exogenous wealth shock also indicate a positive relationship between self-employment entry and wealth. 
2SLS estimation strategy accurately identifies the presences of liquidity constraints even with endogenous saving and correlated abilities. The exogenous shock to wealth results in a higher estimated entry rate into self-employment when liquidity constraints exist in the simulated data, and this evidence differs from the case in which liquidity constraints do not exist and there is no relationship between entry and unexpected wealth shocks. Second, the results indicate that even with smaller sample sizes identification of the presence of liquidity constraints is possible. The lowest reported sample size in the table is equivalent to the job loser sample size when the analysis uses total net worth. ${ }^{33}$ Taken together these results give credence to the empirical approach taken in the remainder of the paper of using exogenous changes in wealth to identify liquidity constraints.

\section{$\underline{\text { Inheritances }}$}

Several previous studies address concerns over the endogeneity of assets by attempting to find suitable instrumental variables or other proxies for wealth, such as inheritances, gifts, lottery winnings or insurance settlements that are otherwise unrelated to the decision to become selfemployed. ${ }^{34}$ Because inheritances and other unanticipated (or at least less-anticipated) lump sum payments are highly correlated with overall net worth, they have become popular in the analysis of entry into self-employment. They are also generally found to have a positive association with the probability of entering or being self-employed, which has been interpreted as providing evidence supporting the liquidity constraint hypothesis.

\footnotetext{
${ }^{33}$ In addition to the simulations reported in Table 6, we perform simulations that assign job loser and nonjob-loser status to various observations based on their values of $\theta$. In particular, "job losers" were defined to be individuals with relatively low values of $\theta$ within narrowly defined asset categories. The simulation results show significantly different effects of assets on entry for the two subsamples consistent with the empirical approach of bifurcating the sample. Results are available upon request.

${ }^{34}$ See Holtz-Eakin, Joulfaian and Rosen (1994a), Lindh and Ohlsson (1996), Blanchflower and Oswald (1998), Fairlie (1999), Taylor (2001), and Schafer, Oleksandr and Weir (2010) for example.
} 
Using our sample from the PSID, we find a similar result that inheritances increase the probability of self-employment entry. We find positive and statistically significant coefficients on net worth instrumented by inheritances for the pooled, job loser and non-job loser samples. ${ }^{35}$ Thus, our main finding holds in the instrumental variables context. Hurst and Lusardi (2004), however, point out that an inheritance may not be a random event, since the receipt of an inheritance may simply signal that the household comes from a wealthy family, which may be correlated with entrepreneurial ability. ${ }^{36}$ Consistent with this argument, they find that both past and future inheritances yield similar instrumental variable results, weakening the credibility of using inheritances as an instrument for wealth. But, it should be noted that this finding does not necessarily rule out the presence of liquidity constraints if family members serve as lenders of last resort to the entrepreneur. A potential business owner may be liquidity constrained in the absence of family assistance, but not constrained with it. This may be especially important in the case where a business owner could only become self-employed if a wealthy family member cosigned for a business loan. If this wealthy family member is also more likely to leave an inheritance then the finding of a positive coefficient on future inheritances would be consistent with the presence of liquidity constraints.

\section{Housing Capital Gains}

In either case, we want to explore alternative exogenous measures of wealth. We present more comprehensive evidence than the previous literature on using a relatively new instrument --

\footnotetext{
${ }^{35}$ Similar to previous studies, we find that the first-stage net worth regressions yield very high F-values for the inheritance variable.

${ }^{36}$ Entrepreneurs may also simply inherit their businesses from previous family members. Estimates from the CBO, SSBF and SCF, however, indicate that very few businesses are inherited (1.6 percent to less than 4.0 percent) suggesting that this is not driving the positive relationship between future inheritances and entrepreneurship (Fairlie and Robb 2006).
} 
gains in housing equity. ${ }^{37}$ The efficacy of this new approach is due to the fact that housing equity represents well over half of net worth for homeowners, and gains in this variable would represent a substantial change in net worth for individuals. The importance of personal commitments in obtaining loans for small businesses (Avery, Bostic and Samolyk 1998), and the finding that personal wealth, primarily through home ownership, decreases the probability of loan denials (Cavalluzzo and Wolken 2005) suggests that home equity may be important for obtaining credit. We also find examining microdata from the 2002 Survey of Small Business Finances that 50 percent of small businesses applying for loans report that collateral was required to secure the loan. Furthermore, prior instruments for exogenous changes in wealth, such as lottery winnings or non-negligible sized inheritances, affect only a relatively small proportion of the overall population, which can be problematic for an instrumental variables approach (see Oreopoulos (2006) for the discussion of this problem). Whereas two-thirds of U.S. families own houses, exogeneous changes in housing equity can represent a large-scale change in net worth that is important to consider when analyzing self-employment entry.

We approach the housing equity variable in a novel way, with two notable aspects. First, identification in recent research relies on variation in housing equity gains across only nine Census divisions in one year in the PSID. ${ }^{38}$ Because analysis at this level may obscure

\footnotetext{
${ }^{37}$ Hurst and Lusardi (2004) use a cross-section of broad regional differences in housing equity as an instrument for household wealth in the business entry equation in the PSID. Also, see Black, de Meza and Jeffreys (1996) for an earlier study finding a positive relationship between net housing equity and business starts using aggregate U.K. data. They use time-series data combined with cross-sectional data for 11 regions in the U.K. Home ownership is also found to be associated with entrepreneurship and obtaining business loans (see for example Johansson 2000 and Cavalluzzo and Wolken 2005).

${ }^{38}$ Hurst and Lusardi (2004) estimate housing equity gains from a regression of changes in house prices from 1985Q1 to 1988Q4 on nine region dummies, initial levels and changes in economic indicators (state GDP per capita and unemployment rates), and demographic characteristics. The inclusion of growth rates in state GDP per capita and unemployment rates controls for differences in local economic growth which may be correlated with entrepreneurship. The regional dummies resulting from this regression therefore capture unaccounted for changes in household wealth and are used as an instrument for 1989 household wealth. Hurst and Lusardi find a highly significant coefficient estimate on the regional dummy in a
} 
underlying trends in smaller geographic regions, we further investigate the relationship between housing appreciation and entrepreneurship by using panel data created by matching consecutive years of the CPS from 1994 to 2004. The CPS panel data allow us to exploit the variation in housing equity across a large number of metropolitan areas over a long period of time. One limitation of these data, however, is that the CPS does not include a measure of net worth. Instead, we include housing appreciation directly into the regressions explaining entry into selfemployment. Households save almost 100 percent of their unanticipated gains in housing equity (Hurst and Lusardi 2004) suggesting that this may not be a serious problem for the analysis. Another limitation of the CPS data is that we cannot identify individuals who were wage/salary workers at the first survey date then suffered a job loss and became self-employed by the second survey date. Thus, we only report estimates for the full sample. ${ }^{39}$

Second, because the ideal instrument would capture only changes in housing values that are completely unanticipated by the individual in addition to being uncorrelated with local economic growth, we consider whether housing appreciation is explained by any additional information. For instance, it may be the case that there are persistent trends in regional housing prices that pre-date the four-year period before the entrepreneurial decision is made. ${ }^{40}$ In this case, the housing price changes would not be unanticipated by the individual, but would still be captured by the regional dummies. To address this issue, we estimate a second set of regressions to also include MSA growth rates in housing prices over the previous four-year period. An

regression determining household wealth. Their estimate implies that households save 94 percent of their housing capital gains, which is consistent with previous findings (Engelhardt 1996, Skinner 1996, and Hurst and Stafford 2005). In the second-stage regression for business entry, they find a negative and statistically insignificant coefficient estimate on the instrumented level of household wealth.

${ }^{39}$ Removing the 2 percent of the sample that is initially unemployed provides similar results -- increases in housing prices lead to higher rates of self-employment entry.

${ }^{40}$ We choose a four-year period to correspond to Hurst and Lusardi's use of regional house price appreciation between 1985Q1 to 1988Q4, but check the sensitivity of the results to alternative period lengths. 
unanticipated shock to wealth in this form is similar to the type of exogenous shock that we introduced in our simulation model.

To create a measure of housing appreciation net of changes in local economic conditions and other factors, we use three different approaches. First, we regress four-year housing appreciation values by MSA and year on initial levels and growth rates or changes in economic indicators (state-level GDP per capital, MSA-level unemployment rates, and MSA-level family income distributions), detailed demographic characteristics by MSA (race, gender, age, marital status, family size, education, family income, labor force participation), and year dummies. MSA-level housing price data are obtained from the Office of Federal Housing Enterprise Oversight (OFHEO). Our second measure of unanticipated housing appreciation is created with a first-stage regression that includes the previous four-year housing appreciation as an additional control. With our third measure, we estimate an additional specification for 1-year unanticipated housing appreciation that includes previous housing appreciation and sums the one-year residuals over a 4-year period. ${ }^{41}$ The residuals for each MSA/year from these first-stage regressions (which have been stripped of any explanatory power related to these various economic indicators) are then included in logit regressions for the probability of becoming a selfemployed business owner.

Table 6 reports marginal effects estimates from the second-stage entrepreneurship logits from all three approaches we use to capture unanticipated housing appreciation. In the first row, the results from our first approach show that the coefficient on housing appreciation is positive and statistically significant. ${ }^{42}$ The point estimate implies that a 10 percent annual increase in

\footnotetext{
${ }^{41}$ The two first-stage specifications that include controls for previous housing appreciation attempt to control for households expecting serially correlated housing prices (Case and Shiller 1989).

${ }^{42}$ We estimate specifications that include residuals for housing appreciation across 9 regions and find small, statistically insignificant estimates in the second-stage entrepreneurship logits.
} 
housing equity leads to a 0.43 percentage point increase in the probability that an individual starts a business in the following year. ${ }^{43}$ This effect is large, representing 17 percent of the mean probability of entrepreneurship. Furthermore, when we switch to including housing appreciation that is unanticipated by the individual we find a very similar coefficient estimate, which is also statistically significant. Results from our second and third approaches are reported in the second and third columns of the table, where we estimated second-stage entrepreneurship logits including the 4-year sum of residuals from first-stage regressions for 1-year housing appreciation. This captures the cumulative unanticipated housing appreciation over the 4-year period experienced by individuals net of changes in economic conditions. The coefficient on housing appreciation is positive and statistically significant.

An important concern with these results is that the positive linear relationship may be driven by the upper tail of the distribution in gains in housing equity. To examine this question, we first estimate regressions with a $5^{\text {th }}$ order polynomial in housing equity gains. Instead of a convex relationship, we find an s-shaped relationship with the upper tail of the distribution flattening out and declining slightly. Furthermore, we find a stronger relationship between housing equity gains and entrepreneurship in the middle of the distribution than for the linear specification. At the middle of the distribution, we find an average derivative of 0.0136 compared to 0.0093 in the linear specification suggesting that the effects of housing equity gains are not concentrated at the upper tail of the distribution.

To investigate this question more directly, Table 7 reports estimates from regressions that include dummy variables for the main percentile categories in the unanticipated housing equity gains distribution. The coefficients generally provide evidence of a positive relationship when

\footnotetext{
${ }^{43}$ These results are not sensitive to the length of the time period used to measure housing capital gains. The coefficient estimates for three-year housing appreciation imply larger annual effects and the coefficient estimates for five-year housing appreciation imply very similar annual effects.
} 
moving up through the percentile categories for housing appreciation. These patterns are consistent with the findings of positive linear and quintic (evaluated at the mean) relationships. The estimates also do not provide evidence of a substantial increase in the probability of entrepreneurship at the $95^{\text {th }}$ percentile in the housing appreciation distribution. In fact, the point estimates are smaller for the $95^{\text {th }}$ percentile than the estimates for the $80^{\text {th }}-95^{\text {th }}$ percentile.

\section{$\underline{\text { Conclusion }}$}

The well-established positive relationship between assets and self-employment entry rates has been traditionally interpreted as evidence in favor of liquidity constraints, but recently this evidence has been challenged. Using PSID data, Hurst and Lusardi (2004) find that the positive relationship often cited in the data is actually due to a relatively unchanging entry rate for individuals with assets at or below the $95^{\text {th }}$ percentile, and then a large increase in entry rates for individuals above this point. The finding is inconsistent with the existence of liquidity constraints, because liquidity constraints should cause entry rates to be rising over the entire asset distribution. We find different results, however, when we separate the sample into job losers and non-job losers. The standard theoretical model of entry into self-employment implies that these two groups face different incentives, and thus different entrepreneurial choices. In particular, involuntary job loss can cause some displaced workers to enter self-employment who otherwise would have remained in the wage and salary sector. We find that entry rates generally increase as wealth rises for each subsample; the result of a constant entry rate in the pooled sample is only due to the changing frequency of job-losers (in comparison with non-job-losers) as assets rise. The positive relationship in the two subsamples is even stronger when we focus on net house values as a measure of net worth, which is available in more survey years. 
Furthermore, the spike in entry rates is due to a sharp increase in entry rates for wealthy job losers, who are on average 50 years old. Given the literature on the adverse consequences of job loss for older workers, the rise in entry rates for this group is attributable to the lack of attractive options in the wage and salary sector. Overall, these findings for the entry rate/wealth relationships in the two subsamples are consistent with liquidity constraints deterring potential entrepreneurs from starting businesses.

We also address the issue of the endogeneity of wealth with two approaches. First, we simulate a two-period variant of the Evans and Jovanovic (1989) model and find significant positive effects of unanticipated shocks to wealth on self-employment entry even in the presence of endogenous saving and correlated abilities. Second, we improve upon the existing literature by using more detailed geographic and time variation of housing prices available in the CPS, and by using an exogenous source of variation in wealth that affects a broader range of the population than previously-used instruments. We find new evidence suggesting that MSA-level unanticipated gains in housing prices -- while controlling for local economic conditions -- are positively associated with self-employment entry. Our estimates from 254 MSAs and 9 time periods indicate that a 10 percent annual increase in housing prices leads to an increase in selfemployment entry rates of 17 percent. We also find that the positive relationship is not being driven by the upper tail of the housing appreciation distribution. These new findings on the relationship between housing appreciation and entrepreneurship from the CPS and those from the reinvestigation of the PSID data are consistent with the liquidity constraint hypothesis and suggest that more research is needed on this important topic. 


\section{Data Appendix:}

The data sets from the PSID are constructed to observe individuals as they move (or did not move) from a state outside of self-employment (either in unemployment or in wage-and-salary employment) into self-employment. Individuals are identified as "self-employed" based upon their self-reports within the "class of worker" variable. As discussed in the text, using different definitions of business ownership and hours restrictions does not affect the main results. There are five main data sets from the PSID used in the analysis. Similar definitions for selfemployment entry are created from matched CPS data. One main sample is used for this analysis.

(1) Data from 1984-1985 and 1989-1990:

The PSID collects very detailed data on household assets every five years, including 1984 and 1989. As such, we prepared a data set with these years in order to analyze the entry patterns of individuals who are observed in the year in which they reported their assets as well as the following year. These data include 10,077 observations.

(2) Data from 1979-1993:

The PSID collects information on net housing equity (the value of the respondent's house minus the remaining mortgage(s) on the house) from 1979 forward (excluding 1982). We use respondents who reported their net house value from 1979 to 1993 and then determined whether or not they became self-employed in the following period. We use the period 1979 to 1993 because job loss is no longer collected by the PSID after 1993. These data include 67,414 observations.

\section{(3) Data from 1979-1996:}

As noted above, the PSID collects information on net housing equity every year from 1979 to 1995 . After 1995, the PSID no longer collected information about net housing equity, only the value of a respondent's house. As such, we limit the sample to this period to use an internally consistent measure of net worth (which was net house value). For the last two years of this period we do not have a measure of job loss and instead use unemployment as a proxy. These data include 82,147 observations.

\section{(4) Data from 1979-2001:}

In 1995 and thereafter, the PSID collects information on the value of a respondent's house every other year. As such, it is only possible to compute two-year entry rates over this period. We examine this period separately because of these changes. These data include 89,958 observations.

\section{(5) CPS Data:}

Panel data is created by matching consecutive years of the Current Population Survey (CPS) Outgoing Rotation Group (ORG) files from 1994 to 2004. The CPS panel microdata include information on 254 MSAs. MSA-level housing price data are obtained from the Office of Federal Housing Enterprise Oversight (OFHEO) and merged to the CPS microdata. These data include 476,033 observations. 


\section{$\underline{\text { References }}$}

Astebro T. and I Bernhardt. 2004. "The Winners Curse of Human Capital," Small Business Economics, 24(1), 2004, 63-78.

Avery, Robert B., Raphael W. Bostic, and Katherine A. Samolyk. 1998. "The Role of Personal Wealth in Small Business Finance," Journal of Banking and Finance, 22: 1019-1061.

Bates, Timothy, and Magnus Lofstrom. 2008. African American Pursuit of Self-Employment, Public Policy Institute of California Working Paper.

Bates, Timothy, and William D. Bradford. 2009. " Venture Capital Investment in Minority Business," Journal of Money Credit and Banking, (forthcoming).

Black, Jane, David de Meza, and David Jeffreys. (1996). "House Prices, The Supply of Collateral and the Enterprise Economy." The Economic Journal. 106 (434):60-75.

Blanchflower, David G. and Oswald, Andrew J. “What Makes and Entrepreneur?” Journal of Labor Economics, 16(1), January, 1998: 26-60.

Bradford, William D. 2003. "The Wealth Dynamics of Entrepreneurship for Black and White Families in the U.S.," Review of Income and Wealth, 49(1): 89-116.

Bruce, Donald. 2000. "Effects of the United States tax system on transitions into selfemployment," Labour Economics, 7(5): 545-574.

Buera, Francisco. 2006. "Persistency of Poverty, Financial Frictions, and Entrepreneurship.” Manuscript, Northwestern Univ., Dept. Econ.

Cagetti, Marco, and Mariacristina De Nardi. 2006. "Entrepreneurship, Frictions and Wealth.” Journal of Political Economy, 114(5): 835-870.

Case, Karl E., and Robert J. Shiller. 1989. "The Efficiency of the Market for Single-Family Homes," American Economic Review, 79(1): 125-137.

Cavalluzzo, Ken, Linda Cavalluzzo, and John Wolken. 2002. "Competition, Small Business Financing, and Discrimination: Evidence from a New Survey,” Journal of Business, Vol. 75(4): 641-679.

Cavalluzzo, Ken and John Wolken. 2005. "Small Business Loan Turndowns, Personal Wealth and Discrimination." Journal of Business, 78(6): 2153-2177.

Chan, Sewin and Stevens, Ann Huff. "Employment and Retirement Following a Late-Career Job Loss.” American Economic Review, 89(2), May, 1999: 211-216. 
Chan, Sewin and Stevens, Ann Huff. "Job Loss and Employment Patterns of Older Workers.” Journal of Labor Economics, 19(2), April, 2001: 484-521.

Demiralp, Berna, and Johanna Francis. 2008. "Wealth, Human Capital, and the Transition to Entrepreneurship” Fordham University, Department of Economics Discussion Paper No: 200809.

Dunn, Thomas and Holtz-Eakin, Douglas. "Financial Capital, Human Capital and the Transition to Self-Employment: Evidence from Intergenerational Links.” Journal of Labor Economics, 18(2), April, 2000: 282-305.

Engelhardt, Gary V. 1996. "House Prices and Home Owner Saving Behavior." Regional Science and Urban Economics. 26 (June): 313-36.

Evans, David S. and Jovanovic, Boyan. “An Estimated Model of Entrepreneurial Choice under Liquidity Constraints.” Journal of Political Economy, 97(4), August, 1989: 808-827.

Evans, David S. and Leighton, Linda S. "Some Empirical Aspects of Entrepreneurship.” American Economic Review, 79(3), June, 1989: 519-535.

Fairlie, Robert W. “The Absence of the African-American Owned Business: An Analysis of the Dynamics of Self-Employment.” Journal of Labor Economics, 17(1), January, 1999: 80-108.

Fairlie, Robert W., and Alicia Robb. 2006. "Families, Human Capital, and Small Businesses: Evidence from the Characteristics of Business Owners Survey," Industrial and Labor Relations Review, 60(2): 225-245.

Fairlie, Robert W., and Alicia M. Robb. 2008. Race and Entrepreneurial Success: Black-, Asian, and White-Owned Businesses in the United States, Cambridge: MIT Press.

Farber, Henry S. “Alternative and Part-Time Employment Arrangements as a Response to Job Loss.” Journal of Labor Economics, 17(4), Part 2, October, 1999: S142-S169.

Farber, Henry S. 2004. “Job Loss in the United States, 1981-2001.” Research in Labor Economics, 23: 69-117.

Federal Reserve, Board of Governors. 2009. "The April 2009 Senior Loan Officer Opinion Survey on Bank Lending Practices," May 2009.

Fonseca, Raquel, Pierre-Carl Michaud, and Thepthida Sopraseuth. 2007. "Entrepreneurship, Wealth, Liquidity Constraints and Start-up Costs,” RAND Working Paper.

Giannetti, M. and Simonov, A.. 2004. "On the determinants of entrepreneurial activity: Social norms, economic environment and individual characteristics," Swedish Economic Policy Review 11(2), 271.313. 
Holtz-Eakin, Douglas, David Joulfaian and Harvey S. Rosen. "Entrepreneurial Decisions and Liquidity Constraints.” RAND Journal of Economics, 25(2), Summer, 1994(a): 334-347.

Holtz-Eakin, Douglas, and Harvey S. Rosen. 2005. "Cash Constraints and Business Start-Ups: Deutschmarks Versus Dollars," Contributions to Economic Analysis \& Policy: Vol. 4: No. 1, Article 1.

Holtz-Eakin, Douglas, John R. Penrod, and Harvey S. Rosen (1996). "Health Insurance and the Supply of Entrepreneurs,” Journal of Public Economics 62(1-2): 209-235.

Hurst, Erik, and Lusardi, Annamaria. "Liquidity Constraints, Household Wealth, and Entrepreneurship.” Journal of Political Economy, 112(2), April, 2004: 319-347.

Hurst, Erik, and Frank P. Stafford. 2005. "Home Is Where the Equity Is: Liquidity Constraints, Mortgage Refinancing and Consumption." Journal of Money, Credit and Banking (forthcoming).

Jacobsen, Louis, Robert Lalonde, and Daniel Sullivan. "Earnings Losses of Displaced Workers.” American Economic Review, 83(4), September, 1993: 685-709.

Johansson, Edvard. "Self-Employment and Liquidity Constraints: Evidence from Finland.” Scandinavian Journal of Economics, 102(1), March, 2000: 123-134.

Kan, Kamhon, and Wei-Der Tsai. 2006. “Entrepreneurship and risk aversion.” Small Business Economics 26 (5): 465-74.

Kerr, William R., and Ramana Nanda. 2011. "Financing Constraints and Entrepreneurship." In Handbook on Research on Innovation and Entrepreneurship, edited by David Audretsch, Oliver Falck and Stephan Heblich, 88-103. Cheltenham, UK: Edward Elgar Publishing, Inc.

Krashinsky, Harry A. “Self-Employment for Less-Educated Men.” Mimeo, University of Toronto, 2004.

Lindh, Thomas, and Henry Ohlsson. 1996. "Self-Employment and Windfall Gains: Evidence from the Swedish Lottery.” Economic Journal, 106(439), November: 1515-1526.

Lindh, Thomas, and Henry Ohlsson. 1998, "Self-employment and wealth inequality," Review of Income and Wealth, 44(1), 25.41.

McCall, Brian P. “The Determinants of Full-Time versus Part-Time Reemployment Following Job Displacement.” Journal of Labor Economics, 15(4), October,1997: 714-734.

Meyer, Bruce 1990. "Why Are There So Few Black Entrepreneurs?," National Bureau of Economic Research, Working Paper No. 3537.

Nykvist, Jenny. 2008. "Entrepreneurship and Liquidity Constraints: Evidence from Sweden," The Scandinavian Journal of Economics. 110(1), 23-43. 
Oreopoulos, Phil 2006. "Estimating Average and Local Average Treatment Effects of Education when Compulsory School Laws Really Matter," American Economics Review, Vol. 96(1) pp. 152-177.

Parker, Simon. 2000. "Evasion of Borrowing Constraints and Small Business Entry and Exit," Small Business Economics, Vol 15, pp. 223-232.

Parker, Simon. 2008. "Entrepreneurship among married couples in the United States: A simultaneous probit approach", Labour Economics, Vol. 15(3), pp. 515-537.

Parker, Simon C. 2009. The Economics of Entrepreneurship. Cambridge: Cambridge University Press.

Paulson, A. L. and Townsend, R. (2004), `Entrepreneurship and_nancial constraints in Thailand', Journal of Corporate Finance 10(2), $229\{262$.

PricewaterhouseCoopers (PwC) and the National Venture Capital Association (NVCA). 2009. MoneyTree $^{\mathrm{TM}}$ Report, based on data provided by Thomson Reuters. www.pwcmoneytree.com

Schafer, Dorothea, Oleksandr Talavera, and Charlie Weir. 2010. "Entrepreneurship, Windfall Gains and Financial Constraints: Evidence from Germany,” DIW Working Paper.

Skinner, Jonathan. 1996. "Is Housing Wealth a Sideshow?" In Advances in the Economics of Aging, edited by David Wise. Chicago: University of Chicago Press (for NBER).

Taylor, Mark P. “Self-Employment and Windfall Gains in Britain: Evidence from Panel Data.” Economica, 68(272), November, 2001: 539-565.

U.S. Census Bureau. 2006. Characteristics of Businesses: 2002: 2002 Economic Census, Survey of Business Owners Company Statistics Series, Washington, D.C.: USGPO.

Yu, Cheng. 2010. "Entrepreneurship and Credit Constraints: Evidence from Rural Households in China” Chinese Academy of Science Working Paper.

Zissimopoulos, Julie, and Lynn Karoly. 2007. "Transitions to Self-Employment at Older Ages the Role of Wealth, Health, Health Insurance, and Other Factors," Labour Economics, v. 14, issue 2, April 2007, p. [269]-295.

Zissimopoulos, Julie, Lynn Karoly, and Qian Gu. 2009. " Liquidity Constraints, Household Wealth, and Self-Employment: The Case of Older Workers," RAND Working Paper. 
Table 1: Sample Means for Non-Self-Employed Workers in 1984 and 1989 Waves of the PSID

\begin{tabular}{|c|c|c|c|c|c|c|}
\hline & \multicolumn{2}{|c|}{$\begin{array}{l}\text { Pooled Sample of Workers in } \\
1984 \text { and } 1989\end{array}$} & \multicolumn{2}{|c|}{$\begin{array}{c}\text { Subsample of Workers who } \\
\text { Experience Job Loss } \\
\text { Prior to Entry } \\
\end{array}$} & \multicolumn{2}{|c|}{$\begin{array}{c}\text { Subsample of Workers who } \\
\text { Do Not Experience Job Loss } \\
\text { Prior to Entry }\end{array}$} \\
\hline & $\begin{array}{c}\text { Enter Self } \\
\text { Employment }\end{array}$ & Non Entrant & $\begin{array}{c}\text { Enter Self } \\
\text { Employment }\end{array}$ & Non Entrant & $\begin{array}{c}\text { Enter Self } \\
\text { Employment }\end{array}$ & Non Entrant \\
\hline Age & $\begin{array}{c}37.94 \\
(11.38)\end{array}$ & $\begin{array}{l}37.93 \\
(11.65)\end{array}$ & $\begin{array}{c}36.38 \\
(10.30)\end{array}$ & $\begin{array}{l}33.65 \\
(9.91)\end{array}$ & $\begin{array}{c}38.85 \\
(11.89)\end{array}$ & $\begin{array}{c}38.64 \\
(11.81)\end{array}$ \\
\hline $\begin{array}{l}\text { High School Graduate } \\
\text { or less education }\end{array}$ & $\begin{array}{c}0.642 \\
(0.480)\end{array}$ & $\begin{array}{c}0.640 \\
(0.480)\end{array}$ & $\begin{array}{c}0.679 \\
(0.469)\end{array}$ & $\begin{array}{c}0.713 \\
(0.453)\end{array}$ & $\begin{array}{c}0.620 \\
(0.486)\end{array}$ & $\begin{array}{c}0.628 \\
(0.483)\end{array}$ \\
\hline Assets & $\begin{array}{l}\$ 69,104 \\
(187,133)\end{array}$ & $\begin{array}{c}\$ 47,142 \\
(171,443)\end{array}$ & $\begin{array}{c}\$ 53,392 \\
(137,833)\end{array}$ & $\begin{array}{l}\$ 15,725 \\
(144,706)\end{array}$ & $\begin{array}{l}\$ 78,298 \\
(210,446)\end{array}$ & $\begin{array}{l}\$ 52,366 \\
(174,956)\end{array}$ \\
\hline Net House Value & $\begin{array}{l}\$ 31,564 \\
(67,477)\end{array}$ & $\begin{array}{l}\$ 25,681 \\
(52,061)\end{array}$ & $\begin{array}{l}\$ 27,424 \\
(54,002)\end{array}$ & $\begin{array}{l}\$ 13,981 \\
(36,939)\end{array}$ & $\begin{array}{l}\$ 33,987 \\
(74,242)\end{array}$ & $\begin{array}{l}\$ 27,627 \\
(53,924)\end{array}$ \\
\hline Hourly Wage & $\begin{array}{l}\$ 13.97 \\
(10.64)\end{array}$ & $\begin{array}{l}\$ 12.77 \\
(7.68)\end{array}$ & $\begin{array}{l}\$ 12.42 \\
(11.10)\end{array}$ & $\begin{array}{l}\$ 10.51 \\
(6.55)\end{array}$ & $\begin{array}{l}\$ 14.56 \\
(10.44)\end{array}$ & $\begin{array}{l}\$ 13.06 \\
(7.76)\end{array}$ \\
\hline Sample Size & 363 & 9,714 & 134 & 1,385 & 229 & 8,329 \\
\hline
\end{tabular}

Standard deviations are listed in parentheses. The sample is constructed from respondents between the age of 21 and 64 in the 1984,1985 , 1989 and 1990 years of the PSID. A respondent is considered to have entered self-employment if he or she is working in the wage and salary sector or is unemployed in 1984 and is self-employed in 1985. A similar procedure is used for 1989 and 1990. See text and Data Appendix for more details. Assets are calculated using the same definition of Hurst and Lusardi (2004); they are the sum of savings and checking accounts, bonds, stocks, IRAs, housing equity (defined as the reported house value minus the remaining mortgage), other real estate, and vehicles minus all debt. 


\section{Table 2: A Logit Analysis of Self-Employment Entry, Using Various Asset Measures}

\begin{tabular}{|c|c|c|c|c|c|c|c|c|c|}
\hline & \multicolumn{3}{|c|}{ Pooled Sample } & \multicolumn{3}{|c|}{ Sub-Sample of Job-Losers } & \multicolumn{3}{|c|}{$\begin{array}{c}\text { Sub-Sample of Non-Job-Losers } \\
\end{array}$} \\
\hline & & Assets & House & & Assets & House & & Assets & House \\
\hline $\begin{array}{c}\text { Assets/ } \\
\$ 100,000\end{array}$ & $\begin{array}{c}0.117^{* * *} \\
(0.040) \\
{[0.003]}\end{array}$ & $\cdots$ & $\ldots$ & $\begin{array}{l}0.164^{* *} \\
(0.080) \\
{[0.040]}\end{array}$ & $\ldots$ & $\ldots$ & $\begin{array}{l}0.116^{* *} \\
(0.051) \\
{[0.023]}\end{array}$ & $\ldots$ & $\ldots$ \\
\hline $\begin{array}{l}40^{\text {th }} \text { to } 60^{\text {th }} \\
\text { Percentile }\end{array}$ & $\cdots$ & $\begin{array}{c}0.229 \\
(0.162) \\
{[0.157]}\end{array}$ & $\begin{array}{c}0.272^{* * *} \\
(0.098) \\
{[0.006]}\end{array}$ & $\cdots$ & $\begin{array}{c}0.241 \\
(0.279) \\
{[0.388]}\end{array}$ & $\begin{array}{l}0.443^{* *} \\
(0.187) \\
{[0.018]}\end{array}$ & $\ldots$ & $\begin{array}{c}0.237 \\
(0.200) \\
{[0.236]}\end{array}$ & $\begin{array}{l}0.228^{* *} \\
(0.113) \\
{[0.044]}\end{array}$ \\
\hline $\begin{array}{l}60^{\text {th }} \text { to } 80^{\text {th }} \\
\text { Percentile }\end{array}$ & $\cdots$ & $\begin{array}{c}0.321^{*} \\
(0.179) \\
{[0.073]}\end{array}$ & $\begin{array}{c}0.264^{* * *} \\
(0.106) \\
{[0.013]}\end{array}$ & $\cdots$ & $\begin{array}{c}0.442 \\
(0.295) \\
{[0.134]}\end{array}$ & $\begin{array}{l}0.487^{* *} \\
(0.199) \\
{[0.014]}\end{array}$ & $\ldots$ & $\begin{array}{c}0.302 \\
(0.221) \\
{[0.172]}\end{array}$ & $\begin{array}{c}0.187 \\
(0.118) \\
{[0.113]}\end{array}$ \\
\hline $\begin{array}{l}80^{\text {th }} \text { to } 95^{\text {th }} \\
\text { Percentile }\end{array}$ & $\cdots$ & $\begin{array}{c}0.377 * \\
(0.222) \\
{[0.089]}\end{array}$ & $\begin{array}{c}0.441^{* * *} \\
(0.116) \\
{[0.000]}\end{array}$ & $\cdots$ & $\begin{array}{c}0.736^{*} \\
(0.409) \\
{[0.072]}\end{array}$ & $\begin{array}{l}0.725^{* * *} \\
(0.217) \\
{[0.001]}\end{array}$ & $\ldots$ & $\begin{array}{c}0.382 \\
(0.264) \\
{[0.148]}\end{array}$ & $\begin{array}{l}0.358^{* *} \\
(0.128) \\
{[0.005]}\end{array}$ \\
\hline $\begin{array}{l}\text { Above } 95^{\text {th }} \\
\text { Percentile }\end{array}$ & $\cdots$ & $\begin{array}{l}0.832^{* * *} \\
(0.285) \\
{[0.004]}\end{array}$ & $\begin{array}{l}0.818^{* * *} \\
(0.168) \\
{[0.003]}\end{array}$ & $\cdots$ & $\begin{array}{l}1.882^{* * *} \\
(0.570) \\
{[0.001]}\end{array}$ & $\begin{array}{l}1.427^{* * *} \\
(0.320) \\
{[0.000]}\end{array}$ & $\ldots$ & $\begin{array}{l}0.591^{*} \\
(0.359) \\
{[0.100]}\end{array}$ & $\begin{array}{l}0.621^{* *} \\
(0.191) \\
{[0.001]}\end{array}$ \\
\hline $\mathrm{N}$ & 10,077 & 10,077 & 67,414 & 1,519 & 1,519 & 9,775 & 8,558 & 8,765 & 57,639 \\
\hline
\end{tabular}

Marginal effects, their standard errors (in parentheses), and their p-values (in square brackets) are reported. Significance is represented by asterisks: ${ }^{* * *}$ Significant at the $1 \%$ level, ${ }^{* *}$ Significant at the $5 \%$ level, ${ }^{*}$ Significant at the $10 \%$ level. The regressions in this table include all of the standard demographic controls (age, age squared, marital status, gender, gender interacted with marital status, and three educational dummy variables) an indicator variable equal to one if the individual had been unemployed in the prior five years and hourly wage prior to entry. The samples for the regression results in columns one, two, four and five are comprised from the 1984 and 1989 waves of the PSID, while the samples in columns three, six and nine are comprised from the 1979-1993 waves of the PSID (excluding 1982, when house value is not reported). In all nine regressions, the analysis is restricted to individuals who are not self-employed in the survey year, and the dependent variable representing entry into self-employment is equal to one if the individual becomes self-employed in the following year, and zero otherwise. See text and Data Appendix for more details. The regressions in columns 2, 3, 5, 6, 8 and 9 contain more than four indicators for net worth, but for brevity's sake, only the highest four categories are included; specifically, the excluded comparison group in columns 2,5 and 8 are individuals whose assets are in the $1^{\text {st }}$ to $40^{\text {th }}$ percentile of the asset distribution, and the comparison group in columns 3,6 and 9 are individuals whose house value is in the $1^{\text {st }}$ to $20^{\text {th }}$ percentile. 
Table 3: A Logit Analysis of Self-Employment Entry, Using Only Net Housing Equity

\begin{tabular}{|c|c|c|c|c|c|c|c|c|c|}
\hline & \multicolumn{3}{|c|}{ Pooled Sample } & \multicolumn{3}{|c|}{ Sub-Sample of Job-Losers } & \multicolumn{3}{|c|}{ Sub-Sample of Non-Job-Losers } \\
\hline & $\begin{array}{c}1979 \text { to } \\
1993\end{array}$ & $\begin{array}{c}1979 \text { to } \\
1996\end{array}$ & $\begin{array}{c}1979 \text { to } \\
2001\end{array}$ & $\begin{array}{c}1979 \text { to } \\
1993\end{array}$ & $\begin{array}{c}1979 \text { to } \\
1996\end{array}$ & $\begin{array}{c}1979 \text { to } \\
2001\end{array}$ & $\begin{array}{c}1979 \text { to } \\
1993\end{array}$ & $\begin{array}{c}1979 \text { to } \\
1996\end{array}$ & $\begin{array}{c}1979 \text { to } \\
2001\end{array}$ \\
\hline $\begin{array}{l}40^{\text {th }} \text { to } 80^{\text {th }} \\
\text { Percentile }\end{array}$ & $\begin{array}{l}0.269^{* * *} \\
(0.086) \\
{[0.002]}\end{array}$ & $\cdots$ & ... & $\begin{array}{l}0.464^{* * *} \\
(0.161) \\
{[0.004]}\end{array}$ & $\ldots$ & ... & $\begin{array}{c}0.258^{* * *} \\
(0.096) \\
{[0.007]}\end{array}$ & $\ldots$ & $\cdots$ \\
\hline $\begin{array}{l}40^{\text {th }} \text { to } 60^{\text {th }} \\
\text { Percentile }\end{array}$ & $\ldots$ & $\begin{array}{c}0.290^{* * *} \\
(0.089) \\
{[0.001]}\end{array}$ & $\begin{array}{l}0.273^{* * *} \\
(0.078) \\
{[0.000]}\end{array}$ & $\ldots$ & $\begin{array}{l}0.343^{* *} \\
(0.172) \\
{[0.046]}\end{array}$ & $\begin{array}{c}0.430^{* * *} \\
(0.163) \\
{[0.008]}\end{array}$ & $\ldots$ & $\begin{array}{c}0.333^{* * *} \\
(0.100) \\
{[0.001]}\end{array}$ & $\begin{array}{l}0.289^{* * *} \\
(0.087) \\
{[0.001]}\end{array}$ \\
\hline $\begin{array}{l}60^{\text {th }} \text { to } 80^{\text {th }} \\
\text { Percentile }\end{array}$ & $\cdots$ & $\begin{array}{l}0.290^{* * *} \\
(0.095) \\
{[0.002]}\end{array}$ & $\begin{array}{l}0.344^{* * *} \\
(0.082) \\
{[0.000]}\end{array}$ & $\ldots$ & $\begin{array}{l}0.414^{* *} \\
(0.184) \\
{[0.024]}\end{array}$ & $\begin{array}{l}0.389^{* *} \\
(0.180) \\
{[0.031]}\end{array}$ & $\ldots$ & $\begin{array}{l}0.301^{* * *} \\
(0.103) \\
{[0.003]}\end{array}$ & $\begin{array}{l}0.323^{* * *} \\
(0.085) \\
{[0.000]}\end{array}$ \\
\hline $\begin{array}{l}80^{\text {th }} \text { to } 95^{\text {th }} \\
\text { Percentile }\end{array}$ & $\begin{array}{l}0.441^{* * *} \\
(0.116) \\
{[0.000]}\end{array}$ & $\begin{array}{l}0.501^{* * *} \\
(0.103) \\
{[0.000]}\end{array}$ & $\begin{array}{l}0.670^{* * *} \\
(0.087) \\
{[0.000]}\end{array}$ & $\begin{array}{l}0.724^{* * *} \\
(0.216) \\
{[0.001]}\end{array}$ & $\begin{array}{l}0.772^{* * *} \\
(0.191) \\
{[0.000]}\end{array}$ & $\begin{array}{l}0.774^{* * *} \\
(0.187) \\
{[0.000]}\end{array}$ & $\begin{array}{c}0.385^{* * *} \\
(0.125) \\
{[0.002]}\end{array}$ & $\begin{array}{l}0.428^{* * *} \\
(0.112) \\
{[0.000]}\end{array}$ & $\begin{array}{l}0.578^{* * *} \\
(0.092) \\
{[0.000]}\end{array}$ \\
\hline $\begin{array}{l}\text { Above } 95^{\text {th }} \\
\text { Percentile }\end{array}$ & $\begin{array}{l}0.818^{* * *} \\
(0.168) \\
{[0.000]}\end{array}$ & $\begin{array}{c}0.879^{* * *} \\
(0.151) \\
{[0.000]}\end{array}$ & $\begin{array}{l}0.934^{* * *} \\
(0.131) \\
{[0.000]}\end{array}$ & $\begin{array}{l}1.426^{* * *} \\
(0.320) \\
{[0.000]}\end{array}$ & $\begin{array}{l}1.349^{* * *} \\
(0.298) \\
{[0.000]}\end{array}$ & $\begin{array}{l}1.244^{* * *} \\
(0.291) \\
{[0.000]}\end{array}$ & $\begin{array}{c}0.482^{* * *} \\
(0.182) \\
{[0.008]}\end{array}$ & $\begin{array}{l}0.621^{* * *} \\
(0.160) \\
{[0.000]}\end{array}$ & $\begin{array}{l}0.675^{* * *} \\
(0.131) \\
{[0.000]}\end{array}$ \\
\hline $\mathrm{N}$ & 67,414 & 82,147 & 89,958 & 9,775 & 11,265 & 12,023 & 57,639 & 70,882 & 77,935 \\
\hline
\end{tabular}

Marginal effects, their standard errors (in parentheses), and their p-values (in square brackets) are reported. Significance is represented by asterisks: ${ }^{* * *}$

Significant at the $1 \%$ level, ${ }^{* *}$ Significant at the $5 \%$ level, ${ }^{*}$ Significant at the $10 \%$ level. The regressions in this table include all of the standard demographic controls (age, age squared, marital status, gender, gender interacted with marital status, and three educational dummy variables), an indicator variable equal to one if the individual had been unemployed in the prior five years and hourly wage prior to entry, and a dummy variable equal to one if the individual does not own a house, and zero otherwise. The samples for the regression results in columns one, four and seven are comprised from the 1979 to 1993 waves of the PSID; the samples for the results in columns two, five and eight are comprised from the 1979 to 1996 waves of the PSID; and the samples in columns three, six and nine are comprised from the 1979-2001 waves of the PSID. The expanded years include inconsistent definitions of some key variables over time. Samples for all nine columns exclude data from 1982, when house value is not reported. In all nine regressions, the analysis is restricted to individuals who are not selfemployed in the survey year, and the dependent variable representing entry into self-employment is equal to one if the individual becomes self-employed in the following year, and zero otherwise. See text and Data Appendix for more details. The excluded comparison group consists of individuals whose net house equity is in the $1^{\text {st }}$ to $40^{\text {th }}$ percentile of the net house equity distribution. 


\section{Table 4: The Average Age for Non-Self-Employed Workers in 1984 and 1989 by Asset Levels}

\begin{tabular}{|c|c|c|c|c|c|c|}
\hline \multirow[t]{2}{*}{$\begin{array}{c}\text { Asset } \\
\text { Percentile }\end{array}$} & \multicolumn{2}{|c|}{$\begin{array}{l}\text { Pooled Sample of } \\
\text { Workers }\end{array}$} & \multicolumn{2}{|c|}{$\begin{array}{l}\text { Subsample of Job } \\
\text { Losers }\end{array}$} & \multicolumn{2}{|c|}{$\begin{array}{c}\text { Subsample of } \\
\text { Non-Job-Losers }\end{array}$} \\
\hline & $\begin{array}{l}\text { Whole } \\
\text { Sample }\end{array}$ & $\begin{array}{c}\text { Entrants } \\
\text { Only }\end{array}$ & $\begin{array}{c}\text { Whole } \\
\text { Subsample }\end{array}$ & $\begin{array}{c}\text { Entrants } \\
\text { Only }\end{array}$ & $\begin{array}{c}\text { Whole } \\
\text { Subsample }\end{array}$ & $\begin{array}{c}\text { Entrants } \\
\text { Only }\end{array}$ \\
\hline $\begin{array}{l}\text { Below } 40^{\text {th }} \\
\text { Percentile }\end{array}$ & $\begin{array}{c}34.28 \\
(11.01)\end{array}$ & $\begin{array}{c}34.26 \\
(10.73)\end{array}$ & $\begin{array}{c}31.18 \\
(8.61) \\
{[0.5978]}\end{array}$ & $\begin{array}{c}33.70 \\
(10.29)\end{array}$ & $\begin{array}{c}35.13 \\
(11.44) \\
{[0.3970]}\end{array}$ & $\begin{array}{c}34.70 \\
(11.10)\end{array}$ \\
\hline $\begin{array}{l}40^{\text {th }} \text { to } 60^{\text {th }} \\
\text { Percentile }\end{array}$ & $\begin{array}{c}35.80 \\
(10.42)\end{array}$ & $\begin{array}{l}34.78 \\
(9.64)\end{array}$ & $\begin{array}{c}33.76 \\
(9.01) \\
{[0.1863]}\end{array}$ & $\begin{array}{l}32.37 \\
(6.20)\end{array}$ & $\begin{array}{c}36.11 \\
(10.59) \\
{[0.2180]}\end{array}$ & $\begin{array}{c}36.08 \\
(10.90)\end{array}$ \\
\hline $\begin{array}{l}60^{\text {th }} \text { to } 80^{\text {th }} \\
\text { Percentile }\end{array}$ & $\begin{array}{c}40.83 \\
(10.81)\end{array}$ & $\begin{array}{c}41.12 \\
(10.68)\end{array}$ & $\begin{array}{c}39.63 \\
(10.01) \\
{[0.1402]}\end{array}$ & $\begin{array}{l}40.21 \\
(9.99)\end{array}$ & $\begin{array}{c}40.97 \\
(10.89) \\
{[0.2135]}\end{array}$ & $\begin{array}{c}41.56 \\
(11.07)\end{array}$ \\
\hline $\begin{array}{l}80^{\text {th }} \text { to } 95^{\text {th }} \\
\text { Percentile }\end{array}$ & $\begin{array}{c}45.54 \\
(10.69)\end{array}$ & $\begin{array}{c}44.15 \\
(11.03)\end{array}$ & $\begin{array}{c}44.04 \\
(10.41) \\
{[0.0606]}\end{array}$ & $\begin{array}{l}43.75 \\
(8.50)\end{array}$ & $\begin{array}{c}45.65 \\
(10.71) \\
{[0.1402]}\end{array}$ & $\begin{array}{c}44.28 \\
(11.86)\end{array}$ \\
\hline $\begin{array}{l}\text { Above } 95^{\text {th }} \\
\text { Percentile }\end{array}$ & $\begin{array}{l}49.51 \\
(9.84)\end{array}$ & $\begin{array}{l}49.85 \\
(7.74)\end{array}$ & $\begin{array}{c}48.87 \\
(7.98) \\
{[0.0151]}\end{array}$ & $\begin{array}{l}48.50 \\
(7.56)\end{array}$ & $\begin{array}{c}49.55 \\
(9.97) \\
{[0.0367]}\end{array}$ & $\begin{array}{l}50.75 \\
(8.06)\end{array}$ \\
\hline $\mathrm{N}$ & 10,077 & 363 & 1,519 & 134 & 8,765 & 243 \\
\hline
\end{tabular}

Standard deviations are listed in parentheses, and column frequencies are listed in square brackets. The sample is constructed from respondents between the age of 21 and 64 in the 1984, 1985, 1989 and 1990 years of the PSID. A respondent is considered to have entered self-employment if he or she is working in the wage and salary sector or is unemployed in 1984 and is self-employed in 1985. A similar procedure is used for 1989 and 1990. Columns one, three and five analyze the age of respondents by asset category for all workers in the sample or subsample, whereas columns two, four and six only consider workers who enter self-employment. See text and Data Appendix for more details. Assets are calculated using the same definition of Hurst and Lusardi (2004); they are the sum of savings and checking accounts, bonds, stocks, IRAs, housing equity (defined as the reported house value minus the remaining mortgage), other real estate, and vehicles minus all debt. 


\section{Table 5: Simulations for the Effects of Assets/\$100,000 on Self-Employment Entry}

\begin{tabular}{|c|c|c|c|c|c|}
\hline$\alpha$ & $\begin{array}{c}1,500 \\
\text { Observations } \\
\end{array}$ & $\begin{array}{c}5,000 \\
\text { Observations }\end{array}$ & 10,000 Observations & 15,000 Observations & $\begin{array}{c}50,000 \\
\text { Observations }\end{array}$ \\
\hline 0.15 & $\begin{array}{l}0.517^{* * *} \\
(0.149) \\
{[0.000]}\end{array}$ & $\begin{array}{l}0.513^{* * *} \\
(0.090) \\
{[0.000]}\end{array}$ & $\begin{array}{l}0.570^{* * *} \\
(0.074) \\
{[0.000]}\end{array}$ & $\begin{array}{l}0.515^{* * *} \\
(0.055) \\
{[0.000]}\end{array}$ & $\begin{array}{l}0.531^{* * *} \\
(0.030) \\
{[0.000]}\end{array}$ \\
\hline 0.2 & $\begin{array}{l}0.538^{* * *} \\
(0.144) \\
{[0.000]}\end{array}$ & $\begin{array}{l}0.504^{* * *} \\
(0.090) \\
{[0.000]}\end{array}$ & $\begin{array}{l}0.595^{* * *} \\
(0.076) \\
{[0.000]}\end{array}$ & $\begin{array}{l}0.538^{* * *} \\
(0.058) \\
{[0.000]}\end{array}$ & $\begin{array}{l}0.548^{* * *} \\
(0.031) \\
{[0.000]}\end{array}$ \\
\hline 0.25 & $\begin{array}{l}0.491^{* * *} \\
(0.139) \\
{[0.000]}\end{array}$ & $\begin{array}{l}0.542^{* * *} \\
(0.094) \\
{[0.000]}\end{array}$ & $\begin{array}{l}0.675^{* * *} \\
(0.083) \\
{[0.000]}\end{array}$ & $\begin{array}{l}0.571^{* * *} \\
(0.060) \\
{[0.000]}\end{array}$ & $\begin{array}{l}0.572^{* * *} \\
(0.032) \\
{[0.000]}\end{array}$ \\
\hline 0.3 & $\begin{array}{l}0.643^{* * *} \\
(0.163) \\
{[0.000]}\end{array}$ & $\begin{array}{l}0.645^{* * *} \\
(0.104) \\
{[0.000]}\end{array}$ & $\begin{array}{l}0.723^{* * *} \\
(0.087) \\
{[0.000]}\end{array}$ & $\begin{array}{l}0.655^{* * *} \\
(0.066) \\
{[0.000]}\end{array}$ & $\begin{array}{l}0.649^{* * *} \\
(0.035) \\
{[0.000]}\end{array}$ \\
\hline 0.35 & $\begin{array}{l}0.901^{* * *} \\
(0.204) \\
{[0.000]}\end{array}$ & $\begin{array}{l}0.899^{* * *} \\
(0.130) \\
{[0.000]}\end{array}$ & $\begin{array}{l}0.952^{* * *} \\
(0.104) \\
{[0.000]}\end{array}$ & $\begin{array}{l}0.891^{* * *} \\
(0.081) \\
{[0.000]}\end{array}$ & $\begin{array}{l}0.981^{* * *} \\
(0.046) \\
{[0.000]}\end{array}$ \\
\hline 0.4 & $\begin{array}{c}2.03^{* * *} \\
(0.310) \\
{[0.000]}\end{array}$ & $\begin{array}{c}2.15^{* * *} \\
(0.212) \\
{[0.000]}\end{array}$ & $\begin{array}{c}2.18^{* * *} \\
(0.169) \\
{[0.000]}\end{array}$ & $\begin{array}{c}2.07^{* * *} \\
(0.129) \\
{[0.000]}\end{array}$ & $\begin{array}{c}2.23^{* * *} \\
(0.075) \\
{[0.000]}\end{array}$ \\
\hline
\end{tabular}

The table reports results from a simulation of a two-period model in which individuals can choose between the wage and salary sector and the self-employment sector in either period. Significance is represented by asterisks: ${ }^{* * *}$ Significant at the $1 \%$ level, ${ }^{* *}$ Significant at the $5 \%$ level, ${ }^{*}$ Significant at the $10 \%$ level; standard errors are reported in parentheses, and p-values are reported in square brackets. The table's regressions use a dependent variable equal to one if the individual "enters" self-employment, and zero otherwise, and an independent variable equal to the individual's assets. Entry is defined as being employed in the wage and salary sector in period one, and the self-employment sector in period two, while non-entry is defined as being employed in the wage and salary sector in both periods. The reported estimates are from two-stage least squares regressions in which an indicator equal to one if the individual has been assigned a randomly generated increase in their assets (this random increase was generated for ten percent of the sample) is used as an instrumental variable. The rows of the table display results from simulations that assign a particular value to $\alpha$, the coefficient on capital in the production function for the self-employment sector. See text for more details. 


\section{Table 6: A Logit Analysis of Self-Employment Entry with Housing Appreciation Current Population Survey, Outgoing Rotation Group Files (1993-2004)}

\begin{tabular}{|c|c|c|c|}
\hline Housing Appreciation & $\begin{array}{c}0.0093^{* * *} \\
(0.0028) \\
{[0.001]}\end{array}$ & $\begin{array}{c}0.0093^{* * *} \\
(0.0028) \\
{[0.001]}\end{array}$ & $\begin{array}{c}0.0172^{* * *} \\
(0.0056) \\
{[0.002]}\end{array}$ \\
\hline $\begin{array}{l}\text { Controls for previous 4-year housing } \\
\text { appreciation }\end{array}$ & No & Yes & No \\
\hline $\begin{array}{l}\text { Uses sum of one-year unanticipated housing } \\
\text { appreciation residuals }\end{array}$ & No & No & Yes \\
\hline
\end{tabular}

\footnotetext{
Significance is represented by asterisks: ${ }^{* * *}$ Significant at the $1 \%$ level, ${ }^{* *}$ Significant at the $5 \%$ level, ${ }^{*}$ Significant at the $10 \%$ level. Marginal effects, their standard errors (in parentheses), and their p-values (in square brackets) are reported. The regressions in this table include all of the standard demographic controls (age, age squared, marital status, gender, gender interacted with marital status, education, central city status region, and year dummies). The samples for the regressions are comprised from the 1993 to 2004 matched CPS ORG files (excluding 1994-95 and 1995-96). In all regressions, the analysis is restricted to individuals who are not self-employed in the first survey year, and the dependent variable representing entry into self-employment is equal to one if the individual becomes self-employed in the following year, and zero otherwise. Standard errors are adjusted for clustering at the MSA level. Housing appreciation is the residual from a regression of four-year MSA-level housing appreciation on MSA averages of race, gender, age, marital status, family size, education, family income, labor force participation, and unemployment, year dummies, state GDP per capita, and growth rates in MSA unemployment rates, state GDP per capita and family income distributions. The second column uses previous 4-year housing appreciation as an additional control in estimating the housing appreciation residual. Housing price data are from the Office of Federal Housing Enterprise Oversight (OFHEO). The third column uses residuals from 1-year housing appreciation regressions with all controls and previous housing appreciation. The residuals are summed to create 4-year unanticipated housing appreciation.
} 


\section{Table 7: A Logit Analysis of Self-Employment Entry with the Housing Appreciation Distribution Current Population Survey, Outgoing Rotation Group Files (1993-2004)}

\begin{tabular}{|c|c|c|c|}
\hline & $\begin{array}{c}\text { Housing } \\
\text { Appreciation }\end{array}$ & $\begin{array}{l}\text { Housing Appreciation } \\
\text { (unanticipated, controls } \\
\text { for previous 4-year } \\
\text { housing appreciation) }\end{array}$ & $\begin{array}{l}\text { Housing Appreciation } \\
\text { (using sum of one-year } \\
\text { unanticipated housing } \\
\text { appreciation residuals) }\end{array}$ \\
\hline $\begin{array}{l}20^{\text {th }} \text { to } 40^{\text {th }} \\
\text { Percentile }\end{array}$ & $\begin{array}{l}-0.0001 \\
(0.0009) \\
{[0.9115]}\end{array}$ & $\begin{array}{c}0.0000 \\
(0.0009) \\
{[0.9999]}\end{array}$ & $\begin{array}{c}0.0008 \\
(0.0009) \\
{[0.3741]}\end{array}$ \\
\hline $\begin{array}{l}40^{\text {th }} \text { to } 60^{\text {th }} \\
\text { Percentile }\end{array}$ & $\begin{array}{l}0.0032^{* * *} \\
(0.0009) \\
{[0.0004]}\end{array}$ & $\begin{array}{l}0.0032^{* * *} \\
(0.0010) \\
{[0.0014]}\end{array}$ & $\begin{array}{c}0.0015^{*} \\
(0.0008) \\
{[0.0608]}\end{array}$ \\
\hline $\begin{array}{l}60^{\text {th }} \text { to } 80^{\text {th }} \\
\text { Percentile }\end{array}$ & $\begin{array}{c}0.0007 \\
(0.0010) \\
{[0.4839]}\end{array}$ & $\begin{array}{c}0.0008 \\
(0.0010) \\
{[0.4237]}\end{array}$ & $\begin{array}{c}0.0013 \\
(0.0008) \\
{[0.1042]}\end{array}$ \\
\hline $\begin{array}{l}80^{\text {th }} \text { to } 95^{\text {th }} \\
\text { Percentile }\end{array}$ & $\begin{array}{l}0.0035^{* * *} \\
(0.0008) \\
{[0.0000]}\end{array}$ & $\begin{array}{l}0.0037^{* * *} \\
(0.0009) \\
{[0.0000]}\end{array}$ & $\begin{array}{l}0.0036^{* * *} \\
(0.0010) \\
{[0.0003]}\end{array}$ \\
\hline $\begin{array}{l}\text { Above 95 } \\
\text { Percentile }\end{array}$ & $\begin{array}{c}0.0028 \\
(0.0017) \\
{[0.0995]}\end{array}$ & $\begin{array}{c}0.0025 \\
(0.0017) \\
{[0.1414]}\end{array}$ & $\begin{array}{c}0.0029 \\
(0.0016) \\
{[0.0699]}\end{array}$ \\
\hline $\begin{array}{l}\text { Sample } \\
\text { Size }\end{array}$ & 476,033 & 472,844 & 475,747 \\
\hline
\end{tabular}

Significance is represented by asterisks: ${ }^{* * *}$ Significant at the $1 \%$ level, ${ }^{* *}$ Significant at the $5 \%$ level, ${ }^{*}$ Significant at the $10 \%$ level. Marginal effects, their standard errors (in parentheses), and their p-values (in square brackets) are reported. The regressions in this table include all of the standard demographic controls (age, age squared, marital status, gender, gender interacted with marital status, education, central city status region, and year dummies). The left out category for housing appreciation is the less than $20^{\text {th }}$ percentile. The samples for the regressions are comprised from the 1993 to 2004 matched CPS ORG files (excluding 1994-95 and 1995-96). In all regressions, the analysis is restricted to individuals who are not self-employed in the first survey year, and the dependent variable representing entry into self-employment is equal to one if the individual becomes self-employed in the following year, and zero otherwise. Standard errors are adjusted for clustering at the MSA level. Housing appreciation is the residual from a regression of four-year MSA-level housing appreciation on MSA averages of race, gender, age, marital status, family size, education, family income, labor force participation, and unemployment, year dummies, state GDP per capita, and growth rates in MSA unemployment rates, state GDP per capita and family income distributions. The second column uses previous 4-year housing appreciation as an additional control in estimating the housing appreciation residual. Housing price data are from the Office of Federal Housing Enterprise Oversight (OFHEO). The third column uses residuals from 1-year housing appreciation regressions with all controls and previous housing appreciation. The residuals are summed to create 4-year unanticipated housing appreciation. 


\section{Appendix Table 1: Sample Means for Non-Self-Employed Workers in the 1979 to 1993 Waves of the PSID}

\begin{tabular}{|c|c|c|c|c|c|c|}
\hline & \multicolumn{2}{|c|}{$\begin{array}{l}\text { Pooled Sample of Workers for } \\
1979 \text { to } 1993\end{array}$} & \multicolumn{2}{|c|}{$\begin{array}{c}\text { Subsample of Workers who } \\
\text { Experience Job Loss } \\
\text { Prior to Entry } \\
\end{array}$} & \multicolumn{2}{|c|}{$\begin{array}{c}\text { Subsample of Workers who } \\
\text { Do Not Experience Job Loss } \\
\text { Prior to Entry }\end{array}$} \\
\hline & $\begin{array}{c}\text { Enter Self } \\
\text { Employment } \\
\end{array}$ & Non Entrant & $\begin{array}{c}\text { Enter Self } \\
\text { Employment } \\
\end{array}$ & Non Entrant & $\begin{array}{c}\text { Enter Self } \\
\text { Employment }\end{array}$ & Non Entrant \\
\hline Age & $\begin{array}{c}37.98 \\
(11.40)\end{array}$ & $\begin{array}{c}38.02 \\
(11.75)\end{array}$ & $\begin{array}{c}36.67 \\
(10.61)\end{array}$ & $\begin{array}{c}33.69 \\
(10.26)\end{array}$ & $\begin{array}{c}38.58 \\
(11.82)\end{array}$ & $\begin{array}{c}38.73 \\
(11.82)\end{array}$ \\
\hline $\begin{array}{l}\text { High School Graduate } \\
\text { or less education }\end{array}$ & $\begin{array}{c}0.601 \\
(0.490)\end{array}$ & $\begin{array}{c}0.643 \\
(0.479)\end{array}$ & $\begin{array}{c}0.617 \\
(0.486)\end{array}$ & $\begin{array}{c}0.678 \\
(0.467)\end{array}$ & $\begin{array}{c}0.594 \\
(0.491)\end{array}$ & $\begin{array}{c}0.637 \\
(0.481)\end{array}$ \\
\hline Net House Value & $\begin{array}{l}\$ 31,768 \\
(64,079)\end{array}$ & $\begin{array}{l}\$ 25,386 \\
(50,107)\end{array}$ & $\begin{array}{l}\$ 32,790 \\
(71,908)\end{array}$ & $\begin{array}{l}\$ 14,725 \\
(35,813)\end{array}$ & $\begin{array}{l}\$ 31,305 \\
(60,219)\end{array}$ & $\begin{array}{l}\$ 27,121 \\
(51,856)\end{array}$ \\
\hline Hourly Wage & $\begin{array}{l}\$ 13.43 \\
(10.06)\end{array}$ & $\begin{array}{l}\$ 12.61 \\
(7.43)\end{array}$ & $\begin{array}{l}\$ 12.10 \\
(9.36)\end{array}$ & $\begin{array}{l}\$ 10.89 \\
(7.09)\end{array}$ & $\begin{array}{l}\$ 13.80 \\
(10.22)\end{array}$ & $\begin{array}{l}\$ 12.82 \\
(7.45)\end{array}$ \\
\hline Sample Size & 1,985 & 65,429 & 619 & 9,156 & 1,366 & 56,273 \\
\hline
\end{tabular}

Standard deviations are listed in parentheses. The sample is constructed from respondents between the age of 21 and 64 in the 1979 to 1993 years of the PSID (excluding 1982, when house value is not reported). A respondent is considered to have entered self-employment if he or she is working in the wage and salary sector or is unemployed one year, and is self-employed in the next. See text and Data Appendix for more details. Net house value is calculated using the reported house value minus the remaining mortgage. 
Appendix Table 2: Post-Entry Major Industry Categories Proportions for Entrants into Self-Employment by Job-Loss Status

\begin{tabular}{ccc}
\hline \hline Major Industry Category & $\begin{array}{c}\text { Lost Job Prior to } \\
\text { Entry into SE }\end{array}$ & $\begin{array}{c}\text { Did Not Lose Job } \\
\text { Prior to Entry into SE }\end{array}$ \\
Construction & $27.99 \%$ & $22.67 \%$ \\
Manufacturing & $5.07 \%$ & $6.67 \%$ \\
Transportation, Communications and Public Utilities & $4.67 \%$ & $6.28 \%$ \\
Trade & $18.05 \%$ & $15.01 \%$ \\
Finance, Insurance and Real Estate & $6.90 \%$ & $6.08 \%$ \\
Service & $37.32 \%$ & $43.28 \%$
\end{tabular}

Pearson Chi-Squared Statistic $=11.86$, p-value $=0.037$

The sample for the table is comprised from the 1979 to 1993 waves of the PSID, excluding data from 1982 (when house value is not reported), and is limited to individuals who entered into self-employment during this period. The sample is bifurcated into two groups: individuals who entered self-employment directly after job loss, and individuals who entered self-employment without losing their job prior to entry. Both columns report the post-entry industry percentage of each subsample, and the final row of the table reports the Chi-Squared statistic of the null hypothesis that the two groups have the same distribution across these industry categories, which is rejected by the data. 
Figure 1: Self-Employment Entry Rates by Pre-Entry Asset Levels

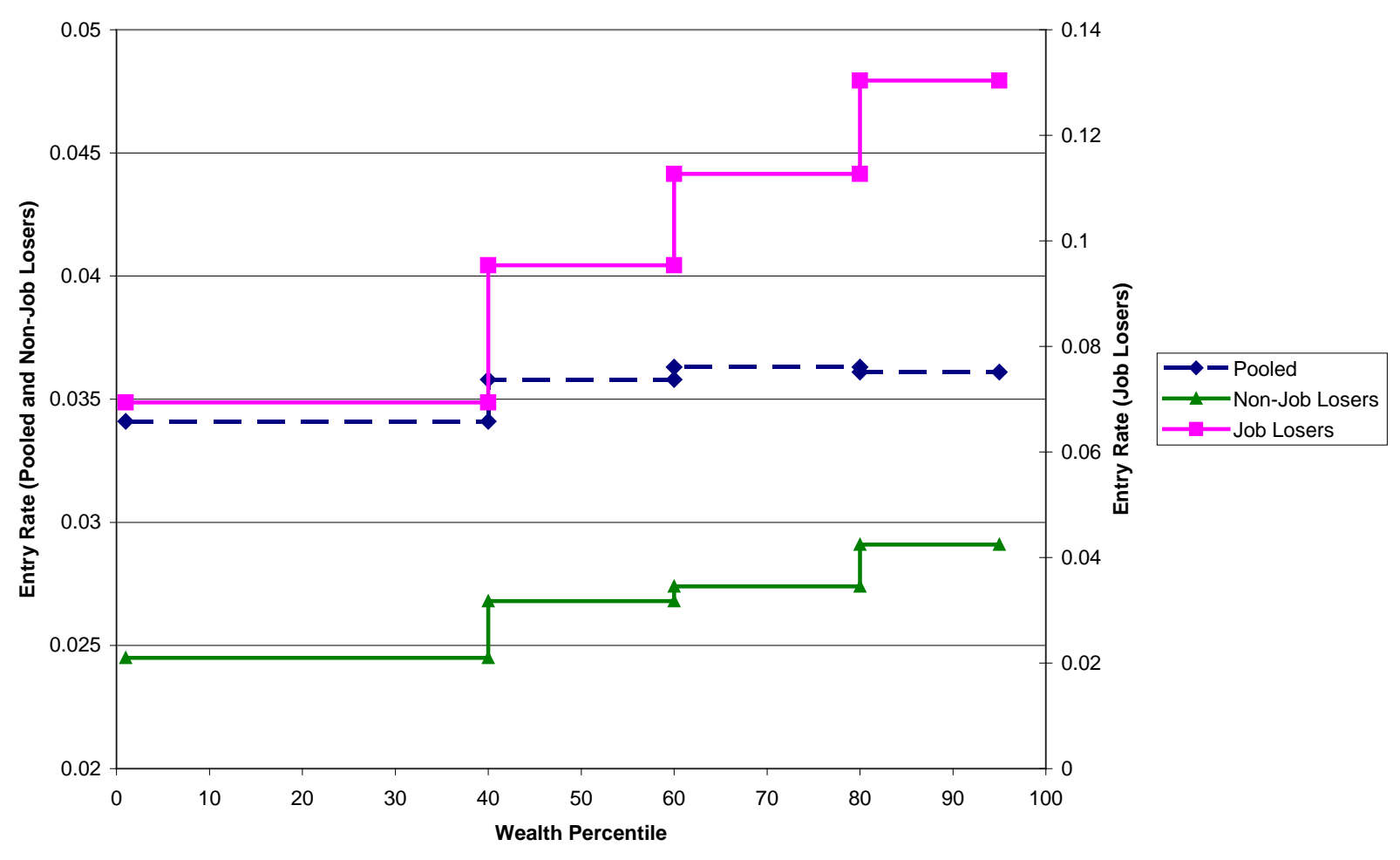


Figure 1A: Self-Employment Entry Rates by Pre-Entry Net House Values

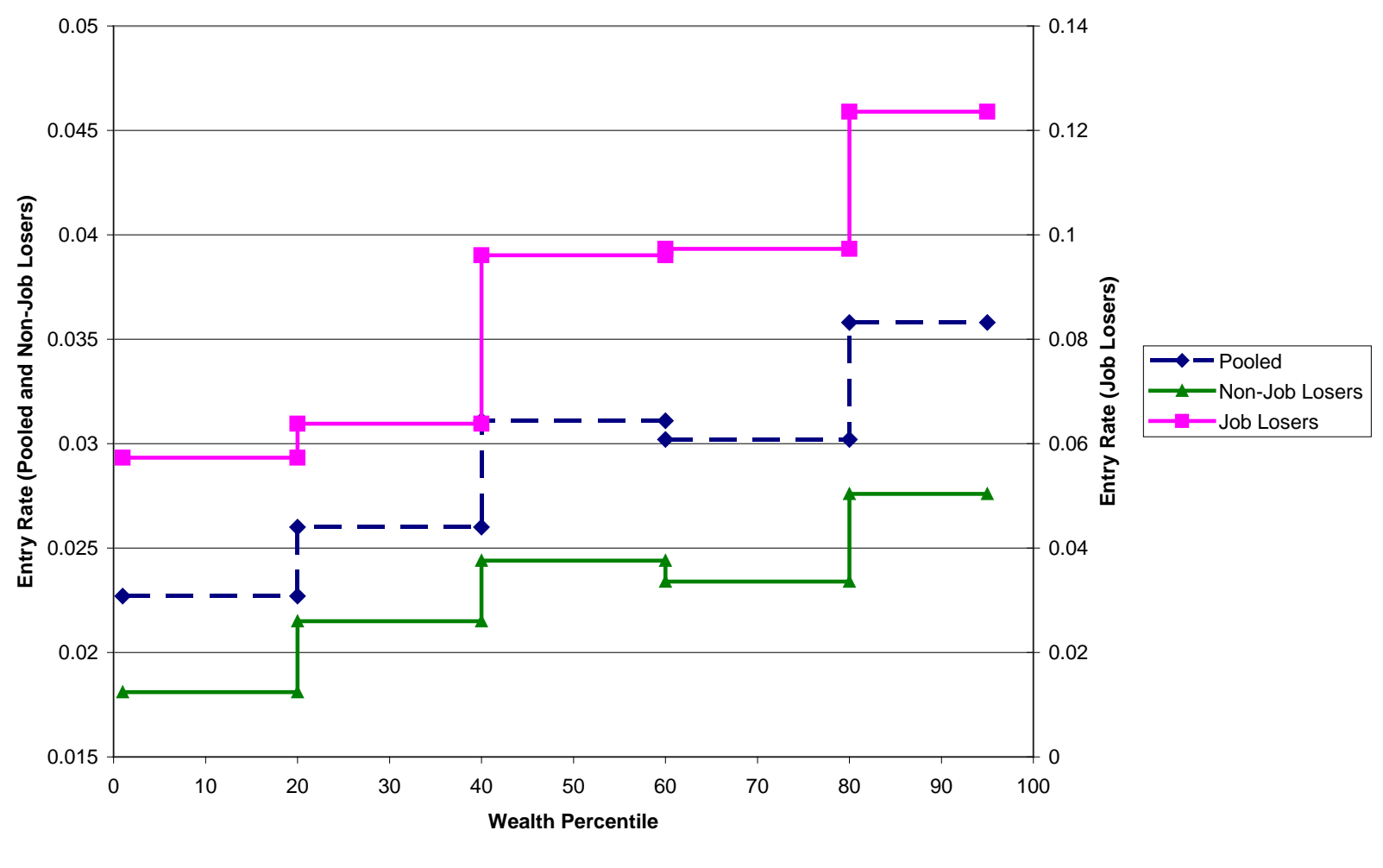


Appendix Figure 1: Self-Employment Entry Rates by Pre-Entry Asset Levels

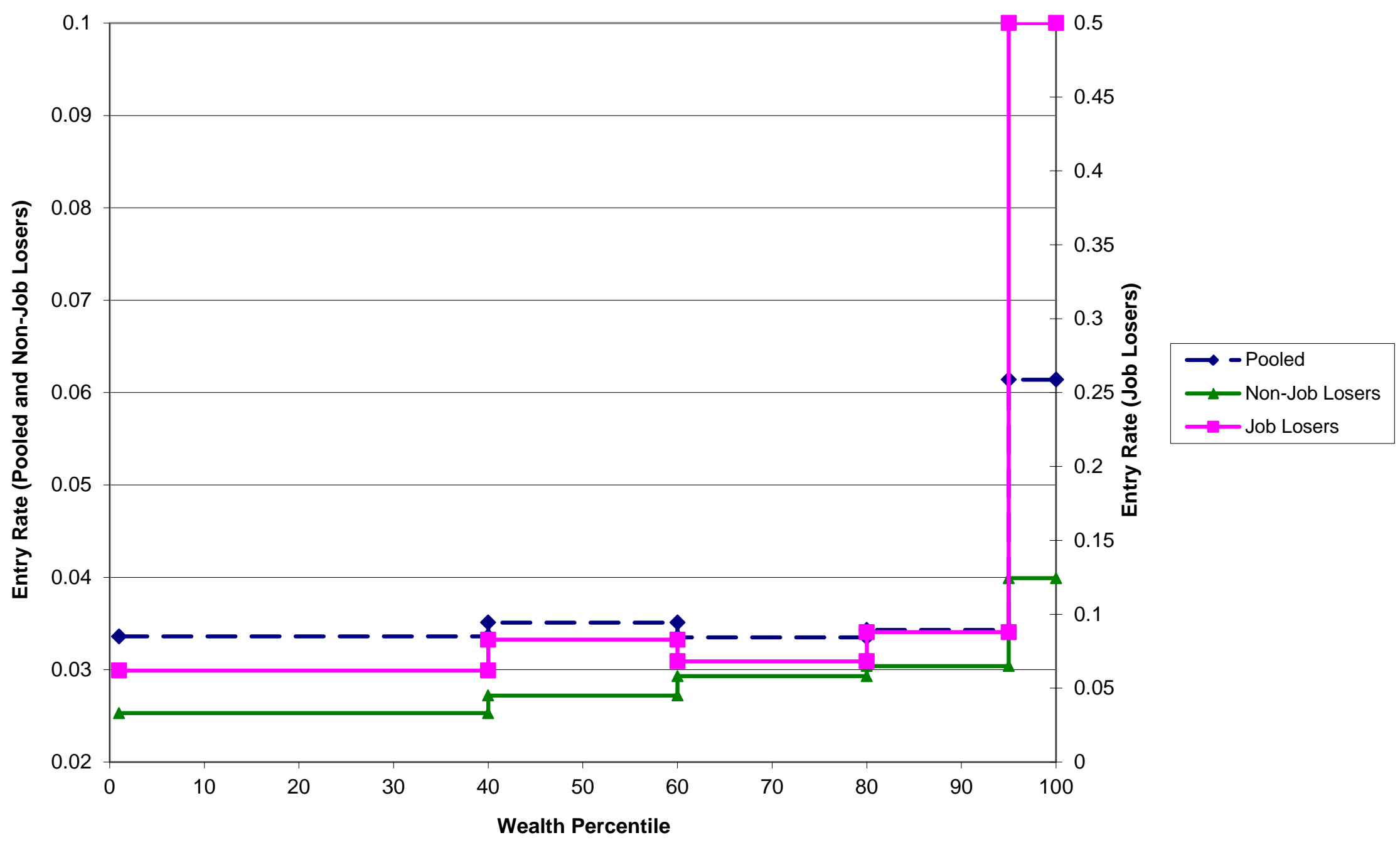




\section{Appendix Figure 1A: Self-Employment Entry Rates by Pre-Entry Net House Values}

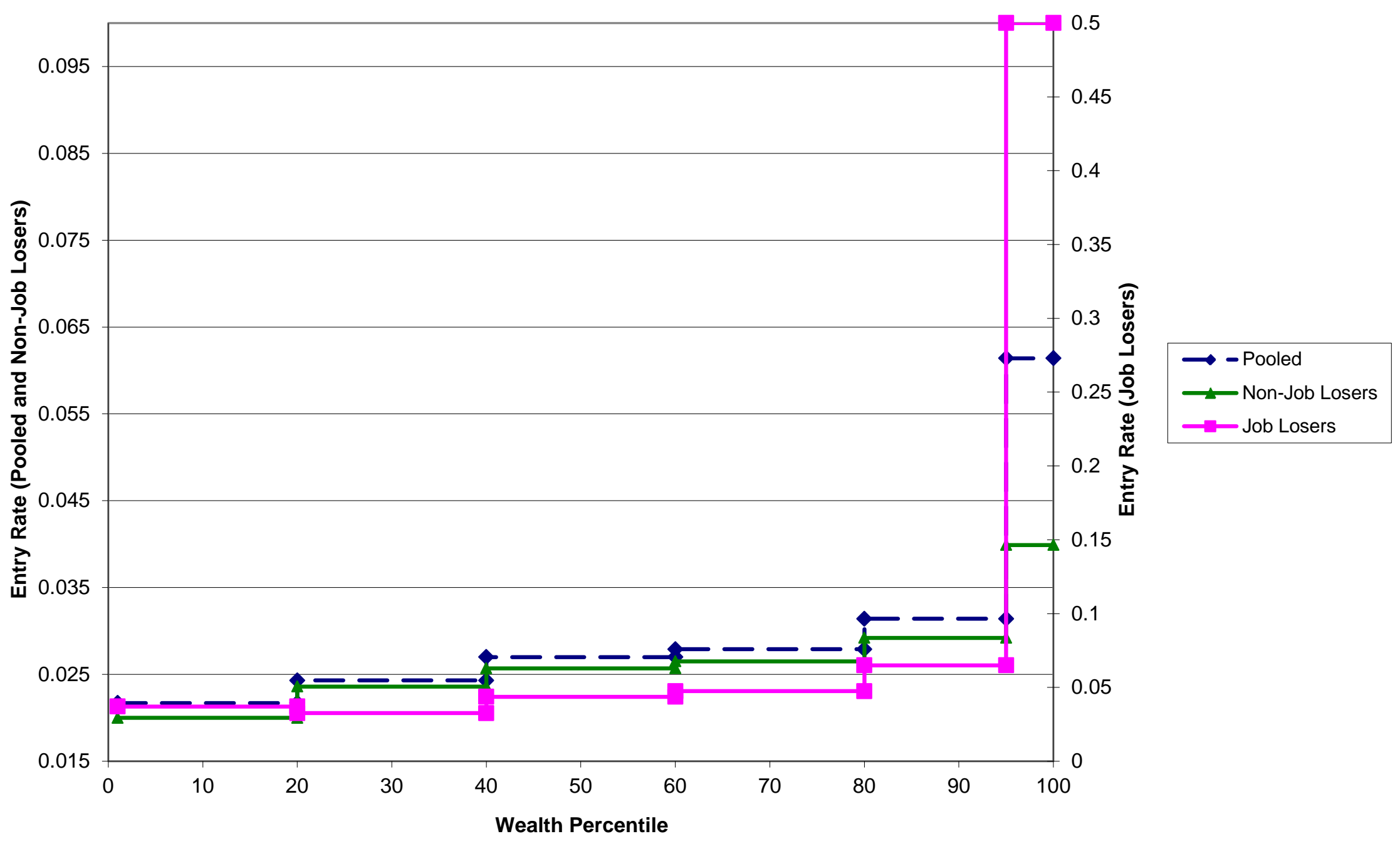

